\title{
Archaeological Survey of Three Land Parcels and Shovel Testing of Four Sites at Camp Bowie, Brown County, Texas
}

Russell D. Greaves

Follow this and additional works at: https://scholarworks.sfasu.edu/ita

Part of the American Material Culture Commons, Archaeological Anthropology Commons, Environmental Studies Commons, Other American Studies Commons, Other Arts and Humanities Commons, Other History of Art, Architecture, and Archaeology Commons, and the United States History Commons

Tell us how this article helped you.

This Article is brought to you for free and open access by the Center for Regional Heritage Research at SFA ScholarWorks. It has been accepted for inclusion in Index of Texas Archaeology: Open Access Gray Literature from the Lone Star State by an authorized editor of SFA ScholarWorks. For more information, please contact cdsscholarworks@sfasu.edu. 


\section{Archaeological Survey of Three Land Parcels and Shovel Testing of Four Sites at Camp Bowie, Brown County, Texas}

\section{Creative Commons License}

\section{(c) (1) \&}

This work is licensed under a Creative Commons Attribution-NonCommercial 4.0 International License 


\section{Archaeological Survey of Three Land Parcels and Shovel Testing of Four Sites at Camp Bowie, Brown County, Texas}

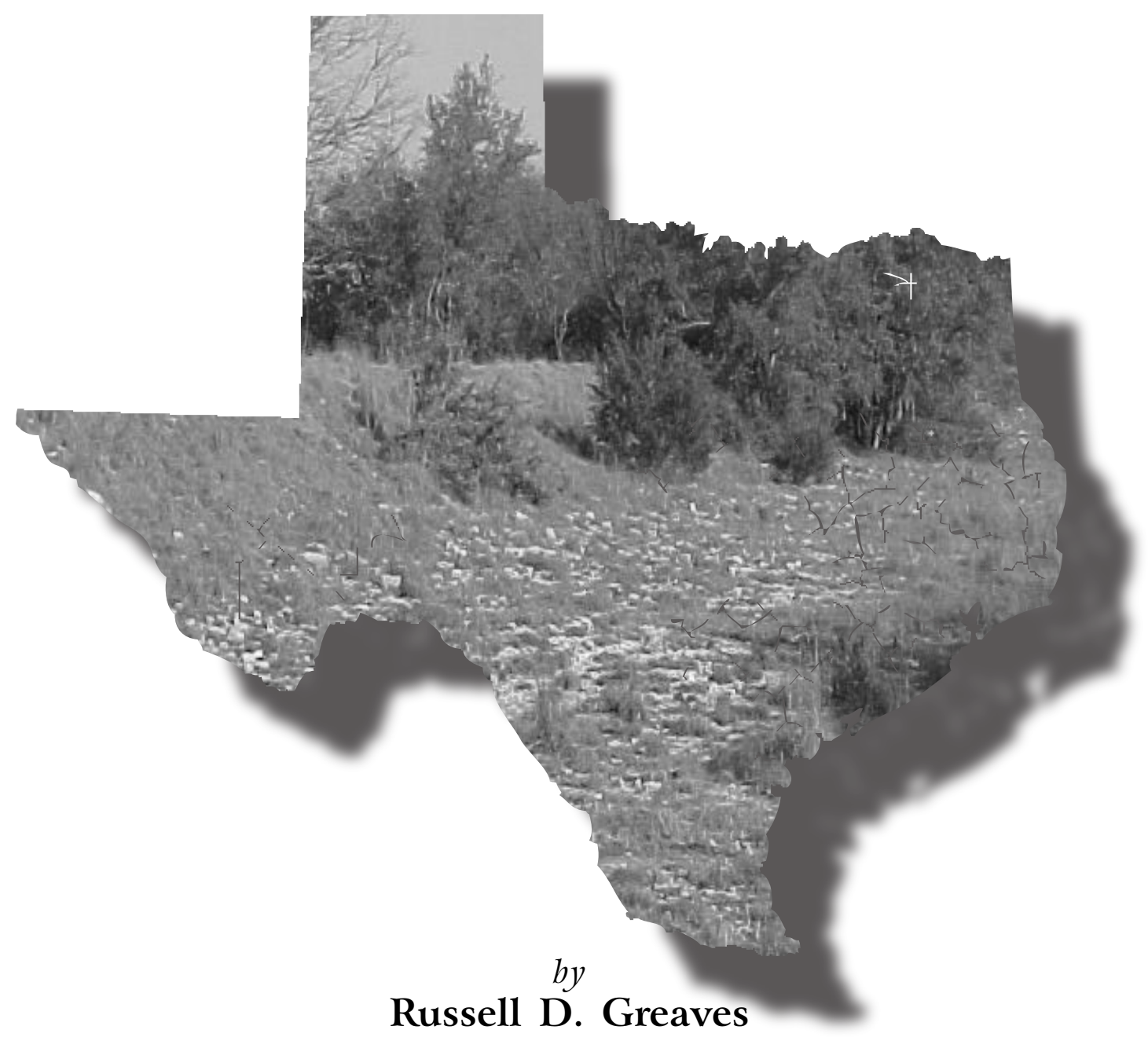

with contributions by

Raymond P. Mauldin and Cory J. Broehm

The Adjutant General's Department of Texas

Directorate of Facilities and Engineering Environmental Branch, Austin, Texas
Center for Archaeological Research The University of Texas at San Antonio Archaeological Survey Report, No. 328 


\title{
Archaeological Survey of Three Land Parcels and Shovel Testing of Four Sites at Camp Bowie, Brown County, Texas
}

\author{
by \\ Russell D. Greaves
}

with contributions by

Raymond P. Mauldin and Cory J. Broehm

Raymond P. Mauldin

Principal Investigator

Texas Antiquities Permit No. 2310

Prepared for:

Adjutant General's Department of Texas

Directorate of Facilities and Engineering

Environmental Branch, Austin, Texas http://www.agtx-ev.pollution.org
Prepared by:

Center for Archaeological Research The University of Texas at San Antonio Archaeological Survey Report, No. 328 http://car.utsa.edu

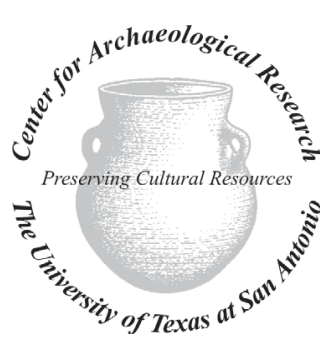

Ccopyright 2002 
The following information is provided in accordance with the General Rules of Practice and Procedure, Chapter 41.11 (Investigative Reports), Texas Antiquities Committee:

1. Type of investigation: intensive survey and testing

2. Project name: Camp Bowie IV: survey of three land parcels and testing of four sites

3. County: Brown

4. Principal investigator: Raymond P. Mauldin

5. Name and location of sponsoring agency: Adjutant General's Department of Texas, Environmental Division, AGTX-EV, P.O. Box 5218, Austin, Texas, 78763-5218

6. Texas Antiquities Permit No.: 2310

7. Published by the Center for Archaeological Research, The University of Texas at San Antonio, 6900 N. Loop 1604 W., San Antonio, Texas 78249-0658, 2002

A list of publications offered by the Center for Archaeological Research is available. Call (210) 458-4378; write to the Center for Archaeological Research, The University of Texas at San Antonio, 6900 N. Loop 1604 W., San Antonio, Texas 78249-0658; e-mail to car@lonestar.utsa.edu; or visit CAR's web site at http://car.utsa.edu. 


\begin{abstract}
:
Pedestrian survey and shovel testing of three land parcels and shovel testing of four previously identified archaeological sites in Camp Bowie, Brown County, Texas, was performed by the Center for Archaeological Research (CAR) at The University of Texas at San Antonio during October and November of 2001. This work, conducted under Texas Antiquities Permit No. 2310, was undertaken as a result of recommendations from Wormser and Sullo-Prewitt (2001) following their archaeological survey and site recording efforts.
\end{abstract}

Three areas of Camp Bowie were surveyed and shovel tested. Parcel 1 is 74 acres ( 30 ha) in extent and 46 shovel tests were excavated in this area. One new site (41BR522) was identified at the northern margin of this survey area. 41BR522 is a small burned rock midden site. Seven additional shovel tests were excavated on this site. One Late Prehistoric projectile point fragment was recovered during shovel testing of 41BR522. Excluding the units on 41BR522, only three shovel tests within Parcel 1 contained subsurface lithics. All of these artifacts represent isolated finds (IF). One additional shovel test had a single animal bone that may not be cultural and is considered an IF. Parcel 2 covers 64 acres ( $26 \mathrm{ha}$ ) and 33 shovel tests were placed within this area. None of the shovel tests in Parcel 2 produced any subsurface archaeological material. Parcel 3 is 62 acres ( $25 \mathrm{ha}$ ) and 43 shovel tests were excavated in this part of Camp Bowie. One shovel test produced two heat-fractured lithics that are not unambiguously cultural in origin. 41BR522 is recommended for additional testing to determine its State Archeological Landmark (SAL) and National Register of Historic Places (NRHP) eligibility. None of the other areas of the three survey parcels contain cultural resources that are considered SAL or NRHP eligible. In the event of deep or extensive excavation of the alluvial soils in Parcel 1, archaeological monitoring is recommended to identify any potential impacts to resources below the $60 \mathrm{~cm}$ depth investigated by this project. Normal military use of this area may proceed without further consultation with the Texas Historical Commission (THC).

In response to recommendations by Wormser and Sullo-Prewitt (2001), four previously recorded archaeological sites were revisited (41BR248, 41BR467, 41BR469, and 41BR471). Site 41BR248 could not be relocated. No surface or subsurface artifacts were identified at the plotted site location. Four shovel tests were excavated within the identified site location, but no cultural materials were encountered. Either naturally fractured local chert has been mistaken for cultural artifacts or the plotted location is not correct for 41BR248. Four shovel tests were excavated in 41BR467, a low-density lithic scatter. No artifacts were recovered from the shovel tests. Four bifaces and two cores were recovered from the surface of this site. Six shovel tests were placed on 41BR469, a low-density lithic scatter. One shovel test contained a single subsurface flake. 41BR471 is a small, relatively dense lithic scatter. Four shovel tests were excavated on this site. One shovel test contained a single lithic. There were no other indications of subsurface archaeological deposits. Surface artifacts included one Late Prehistoric projectile point. Surface visibility at these sites exceeded 30 percent and the number of shovel tests is considered sufficient to determine the significance of these cultural resources. 41BR248 could not be identified at its previously plotted location, if this site still exists -it requires relocation and testing. Additional examination is recommended for 41BR471. Following re-examination and testing, no further characterization of 41BR467 and 41BR469 is considered necessary. With the exception of 41BR471 and 41BR248, no further archaeological work is recommended and scheduled use of this area may proceed without further consultation with THC.

Two additional sites, re-examined in February of 2001 to determine their SAL and NRHP eligibility, are also included in this report (41BR392 and 41BR523). Two shovel tests were excavated in 41BR392 to examine a prehistoric burned rock midden at this previously identified historic site. One Middle Archaic Bulverde point was recovered from the surface of 41BR392. 41BR523 is a World War II-era live grenade court. This site was described but no shovel tests were considered necessary. Further testing is recommended for the burned rock midden component of 41BR392. No additional archaeological work is considered necessary on 41BR523 and that location is recommended for archaeological clearance.

Recommendations from this project are that the SAL and NRHP eligibility of 41BR392, 41BR471, and 41BR522 is unclear in the absence of additional testing efforts. These sites should be protected and avoided until additional examination can determine their SAL and NRHP eligibility status. 41BR248 could not be located with the information currently available. 
Additional evaluation of this site is still required in relation to previous recommendations by THC. Sites 41BR467, 41BR469, and 41BR523 are considered ineligible as SAL or NRHP properties and no additional archaeological characterization is considered necessary. The three survey parcels examined during this survey and testing project do not contain any significant cultural properties (other than 41BR522 at the periphery of Parcel 1) detectable through shovel testing methods. Parcel 1 is located on deep alluvial soil that could contain deeply buried archaeological deposits. Archaeological monitoring is recommended to identify any potential cultural resources below the $60 \mathrm{~cm}$ depth investigated in Parcel 1 if significant excavation of this area is planned. Normal military use of these areas may proceed without further consultation with THC. 


\section{Table of Contents:}

Abstract tenow

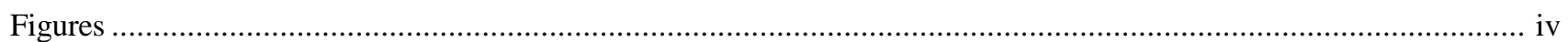

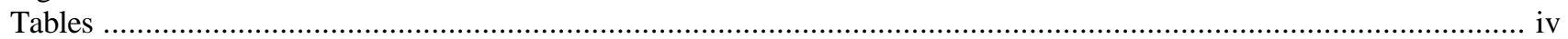

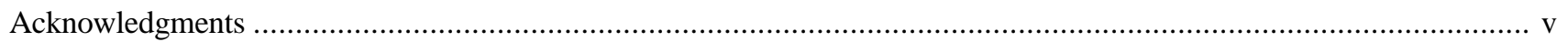

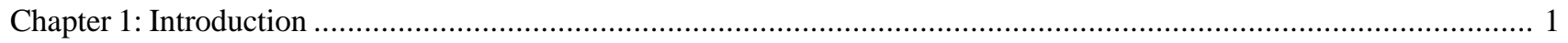

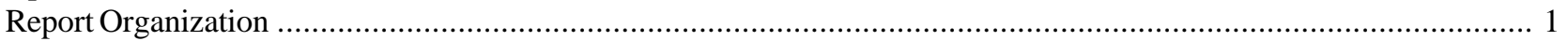

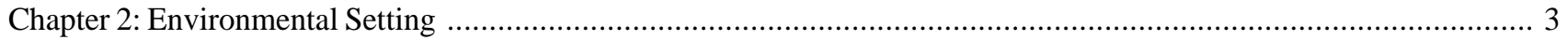

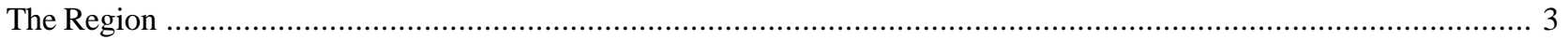

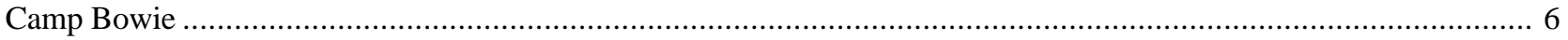

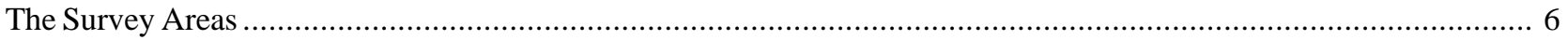

Chapter 3: Prehistoric Cultural Background and Previous Research on Camp Bowie ................................................ 11

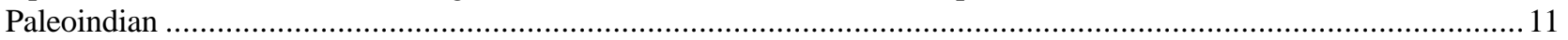

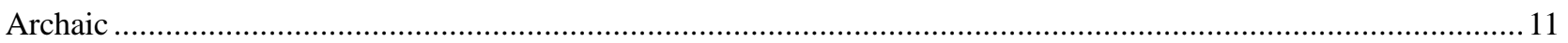

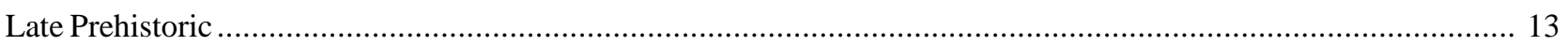

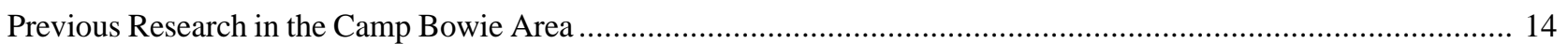

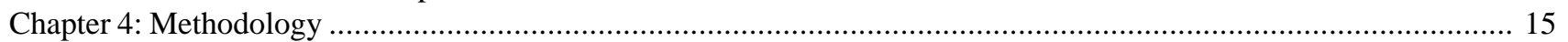

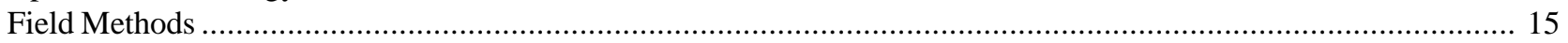

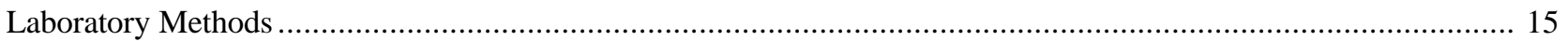

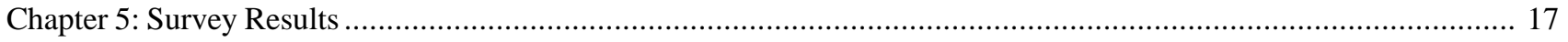

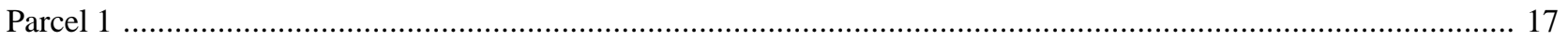

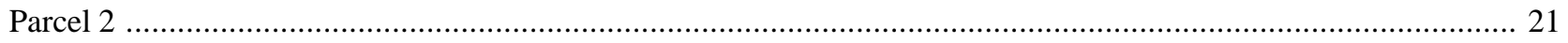

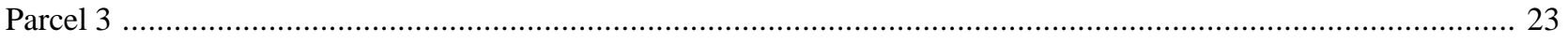

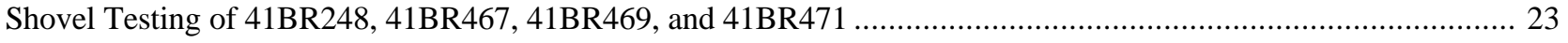

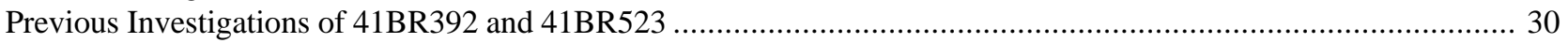

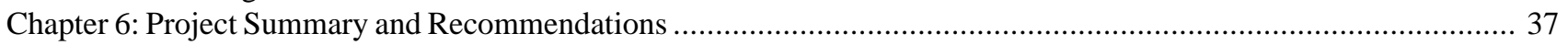

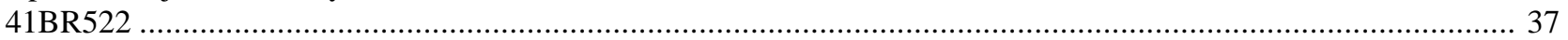

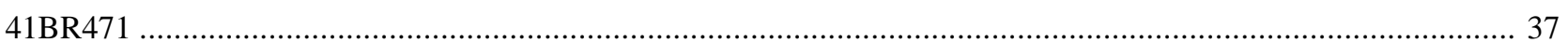

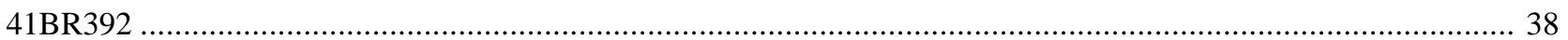

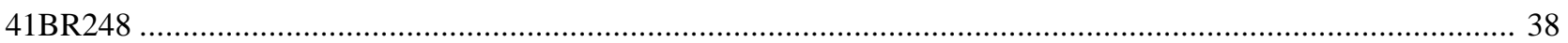

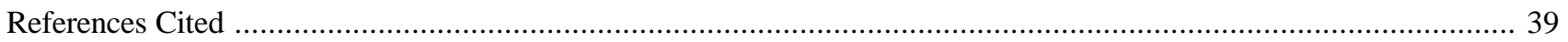

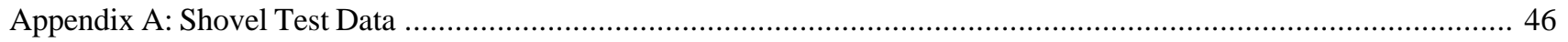




\section{Figures:}

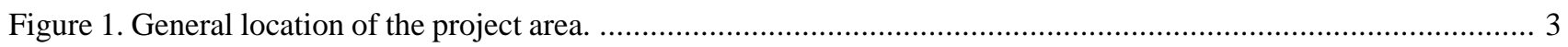

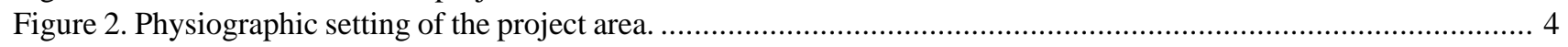

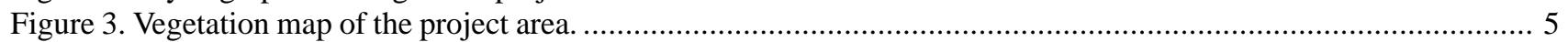

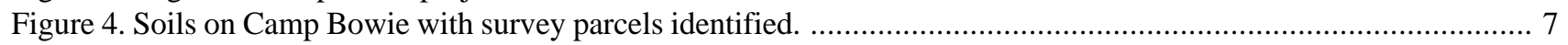

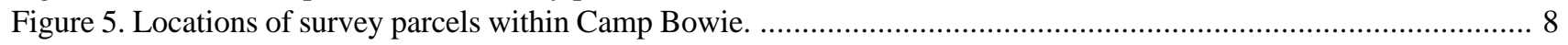

Figure 6. Location of 41BR522 and shovel tests on Parcel 1................................................................... 18

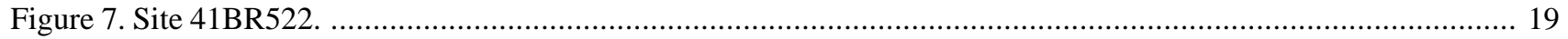

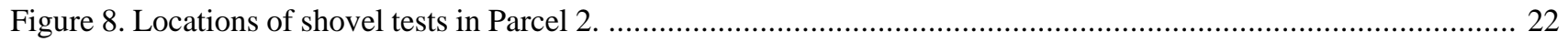

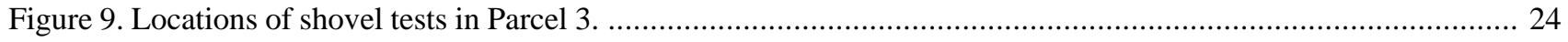

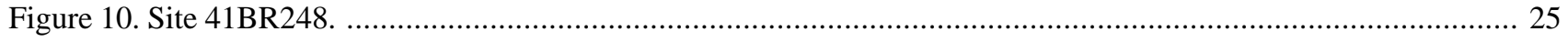

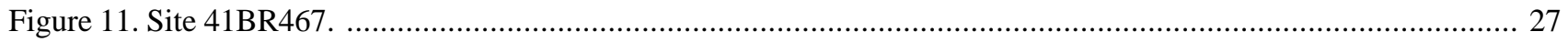

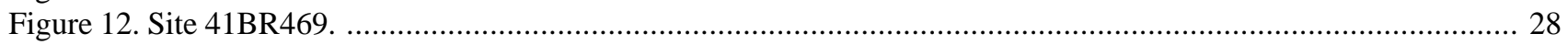

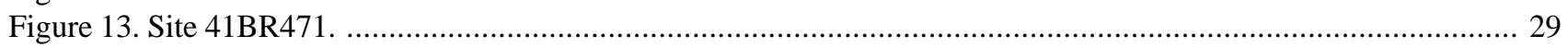

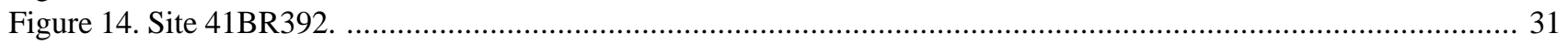

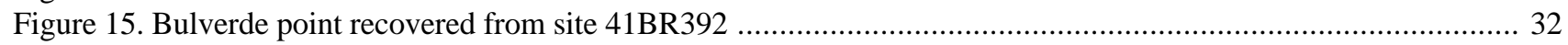

Figure 16. 41BR523, World War II-era range facility with grenade court. .............................................................. 33

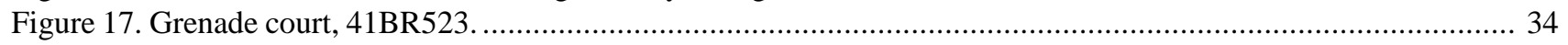

Figure 18. Berm in grenade court of 41BR523, looking northwest. ................................................................... 35

Figure 19. Unexploded World War II-era grenade observed on 41BR523 ....................................................... 35

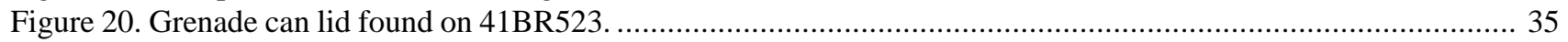

\section{Tables:}

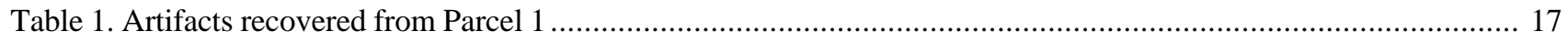

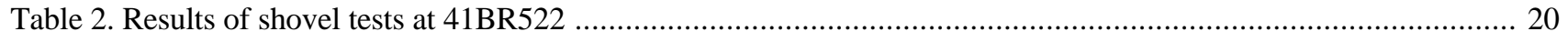

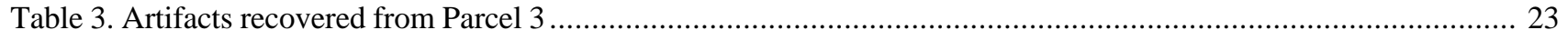

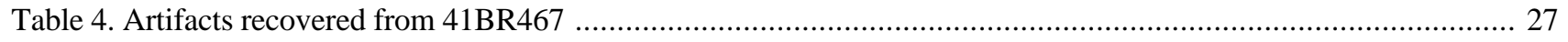

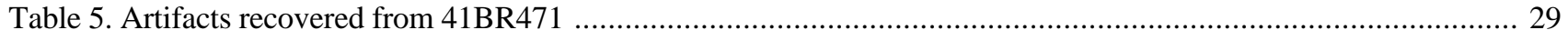

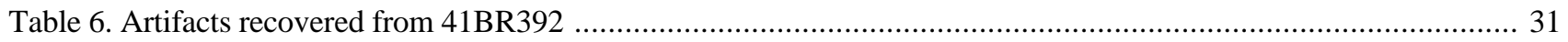

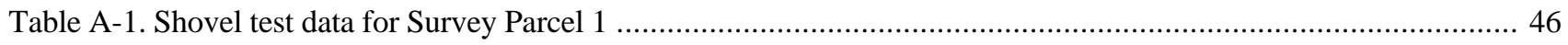

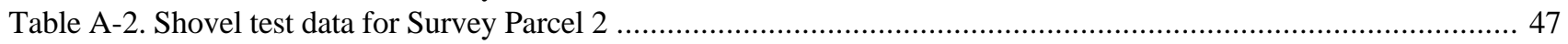

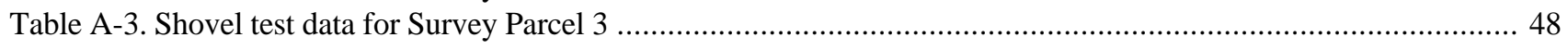

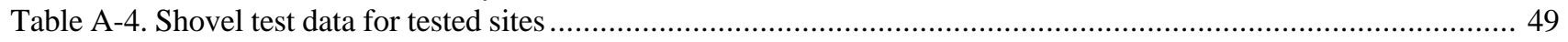

\section{Map Supplement:}

Site Location Map. 


\section{Acknowledgments:}

Dr. Raymond Mauldin was the principal investigator for this work and provided crucial orientation, field assistance, and commentary throughout this project. He also offered significant help during the laboratory work and writing of this report. The archaeological field crew consisted of Bruce Moses, Sylvia Reyna, Bryant Saner, Matthew Senn, and Jason Weston. Jason also served as a crew chief during a portion of the fieldwork. Laboratory processing was overseen by Marybeth Tomka. Laboratory staff included Leonard Kemp, Ruth Mathews, and Sylvia Reyna. Figures were prepared by Rick Young and Bruce Moses. Editing by Johanna Hunziker and Maryanne King has significantly improved the quality of this report. Dr. Steve Tomka advised on many aspects of this project. Assistance at Camp Bowie was provided by several staff members of the Texas Army National Guard. Sergeant Major M. Pilkington and the Security Staff at Camp Bowie were extremely helpful in all aspects of the work. Shellie Sullo-Prewitt of the Texas Army National Guard Environmental Resources Management Branch provided invaluable support for this project 



\section{Chapter 1: Introduction}

This report presents the results of the current project -an intensive survey of three areas and shovel testing of four previously identified archaeological sites within Camp Bowie- as well as a previous project involving the reexamination of two sites in Camp Bowie.

Located in Brown County, Texas, on the Brownwood and Indian Creek USGS 7.5' quadrangles, Camp Bowie was developed by the Army as a training site just prior to World War II. Currently, Camp Bowie is used as a training facility for the Texas Army National Guard.

Pedestrian survey and shovel testing of three land parcels and shovel testing of four previously identified archaeological sites in Camp Bowie was performed by the Center for Archaeological Research (CAR) at The University of Texas at San Antonio during October and November 2001. These investigations were undertaken in compliance with recommendations made in a previously completed archaeological survey and site recording effort by Wormser and Sullo-Prewitt (2001).

One new site, 41BR522, was identified during the current survey. This small burned rock midden site is recommended for additional testing to determine its State Archeological Landmark (SAL) and National Register of Historic Places (NRHP) eligibility. Except for 41BR522, all other areas of the three survey parcels are considered to contain no cultural resources that will be impacted by normal military training use of these areas. Those activities may proceed without any further consultation with the Texas Historical Commission (THC). Because Parcel 1 is on deeper alluvial sediments, there is a possibility that archaeological resources may exist below the depth effectively tested by the current investigations ( $60 \mathrm{~cm}$ below the modern ground surface). It is recommended that if extensive excavations or other activities are planned that may impact deeper sediments monitoring of those disturbances by a professional archaeologist should be performed.

In response to recommendations by Wormser and SulloPrewitt (2001:38-45), revisitation of four previously identified archaeological sites (41BR248, 41BR467, 41BR469, and 41BR471) was also performed as part of this field effort. Site 41BR248 was not relocated in its previously plotted location. Testing and surface inspection did not identify the site as described by Wormser and SulloPrewitt (2001:60). Further inspection of this site's vicinity will determine if it can be relocated, and if found subsequent testing will confirm whether 41BR248 does indeed qualify as a site. Also, additional testing is recommended for site 41BR471. Following re-examination and testing, no further characterization of sites 41BR467 and 41BR469 is considered necessary. With the exception of 41BR471 and the necessary relocating of 41BR248, no further archaeological work is considered necessary at these sites and normal activities may proceed without further consultation with THC.

Two additional sites, re-examined in February of 2001 to determine their SAL and NRHP eligibility, are also included in this report (41BR392 and 41BR523). Further testing is recommended for the burned rock midden component of 41BR392. No additional archaeological work is considered necessary on 41BR523 and training use of that area may proceed without additional consultation with THC.

All work was conducted under Texas Antiquities Permit No. 2310, issued to Dr. Raymond P. Mauldin.

\section{Report Organization}

This report is composed of six chapters, an appendix, and a map supplement. Following this introductory chapter, the Environmental Setting chapter will discuss the general physical environment encountered within the project area. The third chapter, Prehistoric Cultural Background and Previous Research on Camp Bowie, provides a brief overview of the cultural prehistory of the region and previous archaeological investigations in the Camp Bowie area. Chapter Four, Methodology, describes, in detail, the field and laboratory methodologies employed during these investigations and the curatorial requirements. Chapter Five, Survey Results, discusses results from the field and laboratory investigations on a site-by-site basis. The final chapter, Project Summary and Recommendations, presents recommendations for further work and for SAL and NRHP eligibility where warranted. Appendix A presents the shovel test data from the three survey parcels and the tested sites. 
The Camp Bowie facility map with site locations (Map Supplement) is not included in the text of this report, but is located in a pocket at the back. A copy of the map may be obtained by writing to AGTX-EV, Cultural Resources, P.O. Box 5218, Austin, TX 78763-5218. 


\section{Chapter 2: Environmental Setting}

This chapter provides an introduction to the general environment of the region and information on Camp Bowie and the particular survey areas. More detailed information on the climate, geology, and soils can be found in Wormser and Sullo-Prewitt (2001), Nance and Wermund (1993), and Gould (1975). Reviews of Paleoenvironmental data, which are primarily available for areas farther to the south, can be found in Johnson and Goode (1994) and Bousman (1998).

\section{The Region}

Camp Bowie is located in north-central Texas, in Brown County, just south of the town of Brownwood (Figure 1). Brown County covers an area of roughly 615,000 acres
(Clower 1980). The major hydrological feature is Pecan Bayou, a river that enters the county from the northwest and cuts across the county, exiting southeast into the Colorado River. The Colorado River forms the southern boundary of Brown county. Very shallow to deep, loamy and clayey soils cover the uplands of the county, while deep loamy and clayey soils cover the floodplains (Clower 1980).

Physiographically, the area is within the Rolling Plains subdivision (Figure 2), with the Edwards Plateau located just to the east, and the Llano Uplift located to the south (see Gould 1975; Nance and Wermund 1993). The terrain of the Rolling Plains is characterized as gently sloping to hilly as a result of varying erosion of primarily Paleozoic

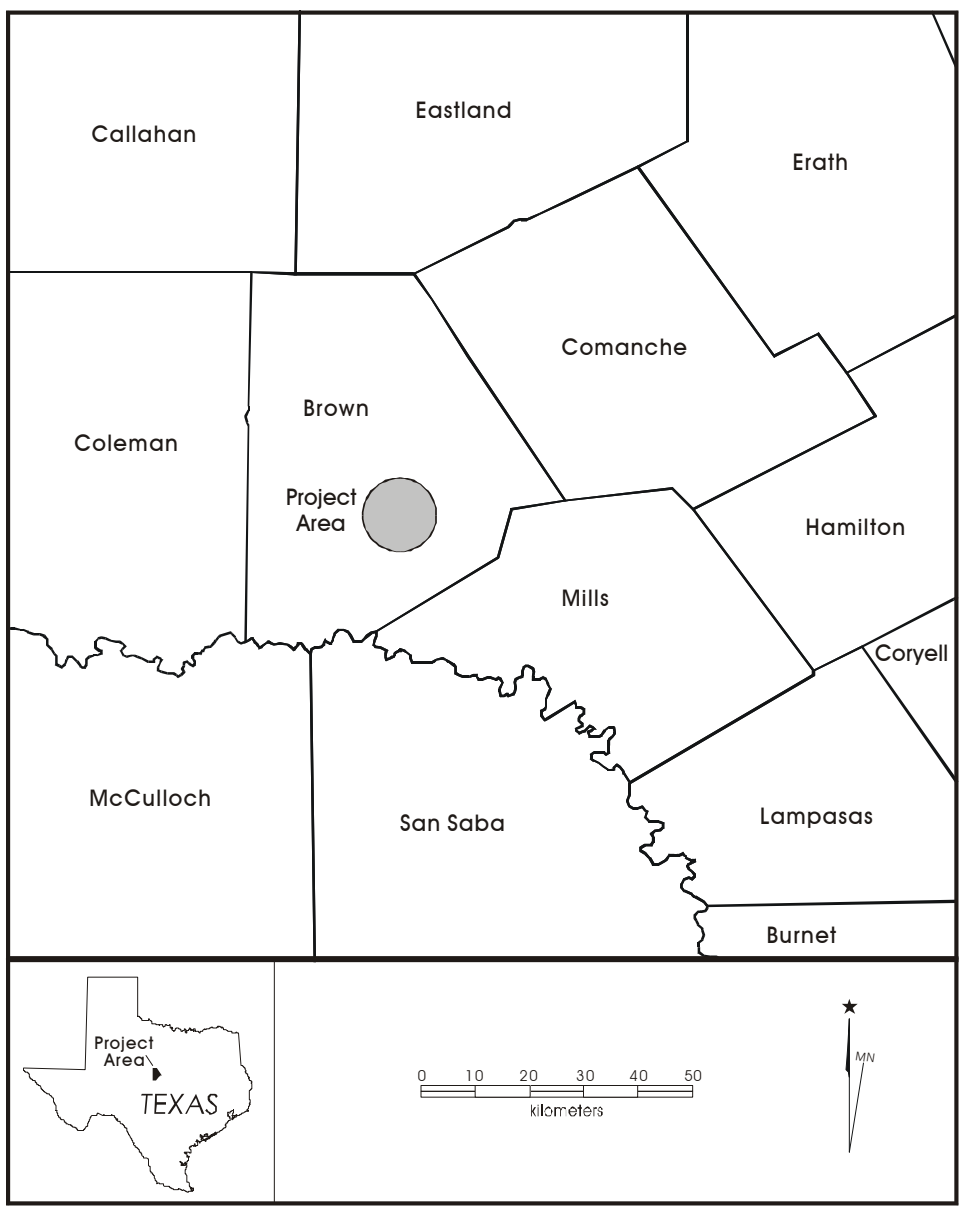

Figure 1. General location of the project area. 


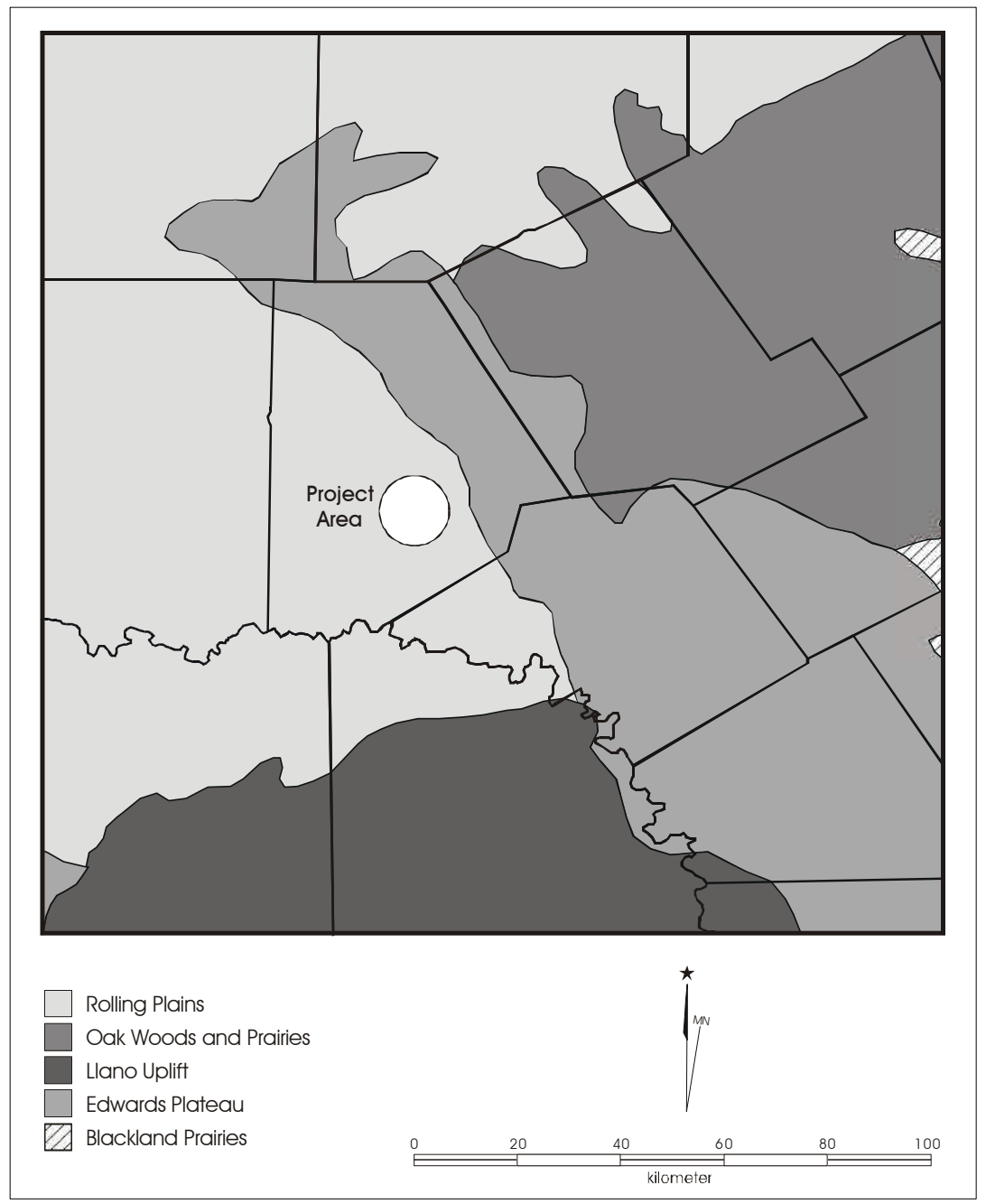

Figure 2. Physiographic setting of the project area.

rock formations (Fenneman 1931:54). The Edwards Plateau has a more rugged, stream-eroded topography, underlain by Cretaceous limestone. The Llano Uplift is essentially an eroded basin composed of Precambrian granitic and metamorphic rock (Swanson 1995).

Characterized as subtropical sub-humid, the climate of the area is one of hot summers and mild winters. The average yearly temperature is 65 degrees $\mathrm{F}$. The growing season averages about 239 days a year, with the average first freeze occurring on November 16 and the last freeze on March 21. Annual precipitation at Brownwood is approximately 26.1 inches $(66 \mathrm{~cm})$. The highest annual rainfall was recorded in
1959 when 42.3 inches $(107.4 \mathrm{~cm})$ of precipitation fell. The driest year was 1954 with only 12.8 inches $(32.5 \mathrm{~cm})$ recorded. During the year, rainfall tends to be bimodal, with peaks in May and September, while December and January are, on average, the driest months (Nance and Wermund 1993).

Figure 3 presents the regional, modern vegetation of the general area. A Live Oak, Mesquite, Ashe Juniper Parkway dominates the southwestern portion of the county, with an Oak, Mesquite, Juniper Parkway bracketing the Pecan Bayou drainage area. Silver bluestem and Texas wintergrass are present along the eastern edge of the county. Much of the county has been cleared for crops and grazing. 


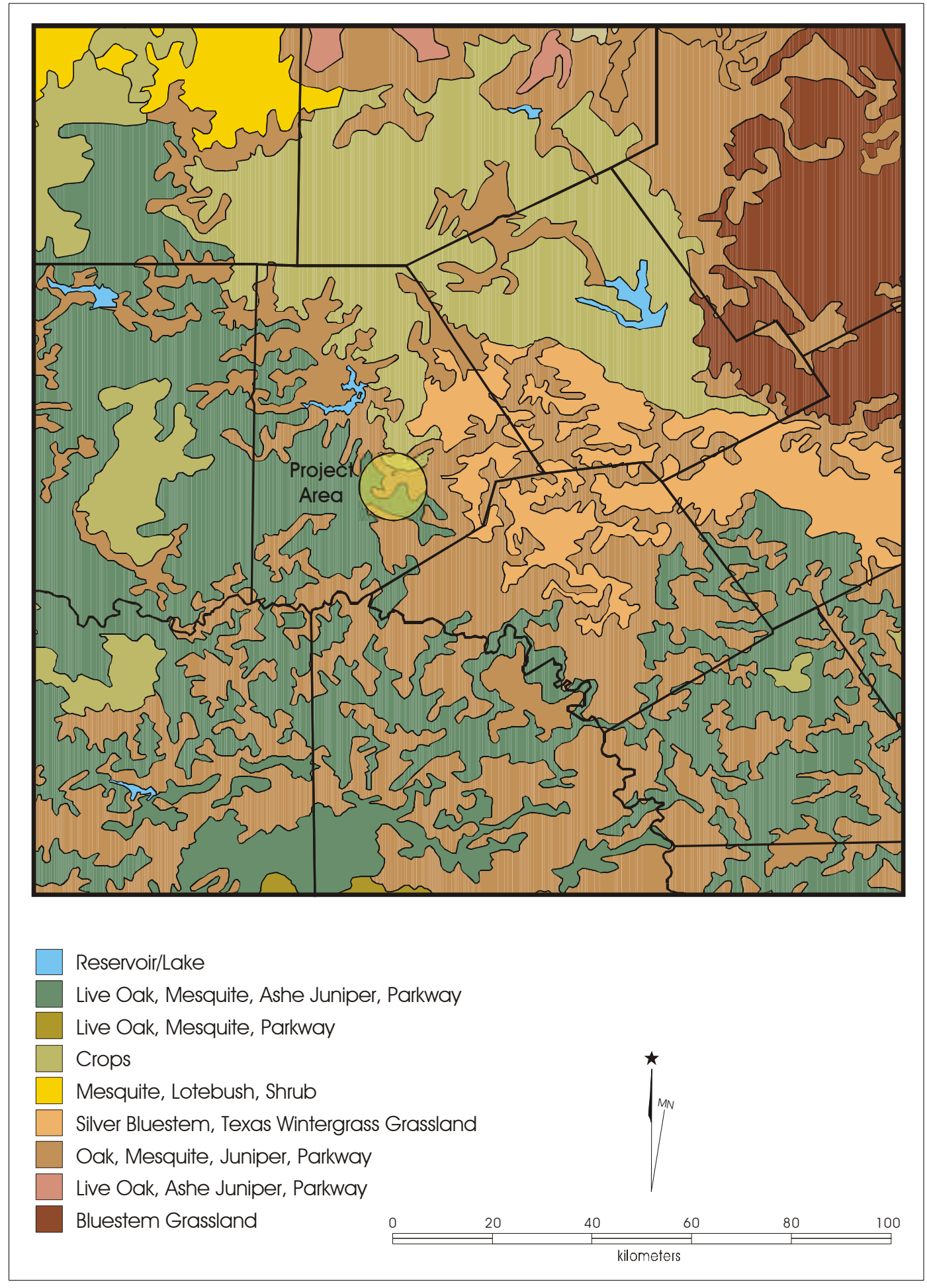

Figure 3. Vegetation map of the project area. 


\section{Camp Bowie}

Camp Bowie covers an area of approximately 9,000 acres. Elevation within the Camp ranges from 1,290 feet (393 m) above mean sea level (AMSL) to just over 1,590 feet AMSL $(485 \mathrm{~m})$. A major topographic feature of the area is a northwest to southeast oriented high ridge of Cretaceous age deposits identified as the Travis Peak Formation (Wormser and Sullo-Prewitt 2001). This major sedimentary deposit includes limestone, sandstone, and conglomerate. Underlying Permian and Pennsylvanian formations, referred to as the Strawn Group, are exposed at various points on the landscape (Nance and Wermund 1993).

Soils of the Camp Bowie area are calcareous sandy loams, silty loams, and clay loams. Upland soils are thin and sandier, with low water-holding capacity. Lowland soils tend to be dominated by clay, with low permeability and high waterholding capacity (Nance and Wermund 1993; Wormser and Sullo-Prewitt 2001). Wormser and Sullo-Prewitt (2001) classified the USDA soil units at Camp Bowie into three general groups designed to monitor their potential to contain buried, intact cultural deposits. The tripartite distinction was based on their evaluation of the soil age and formation history. They suggest that sites on or in the Deleon, Frio, Winters, and Nukrum soils have a moderate-to-high potential for buried archaeological material. Soils with low-tomoderate potential for buried, intact sites include Pedernales fine sandy loam and Sagerton clay loam. The remaining soils have a low probability for containing buried cultural deposits with integrity. The relationship of the three survey parcels to soils at Camp Bowie is provided in Figure 4.

Streams in the Camp Bowie area make up a portion of the Colorado River drainage basin and are small and seasonally active. Drainages to the west of the northwest-southeast trending ridge that cuts through the center of the camp flow into Lewis Creek and eventually into Pecan Bayou to the north, while on the east side of the dividing ridge, drainage is generally into Devils River.

A biological inventory of Camp Bowie, prepared by the Texas Parks and Wildlife Department (1994), provides an extended discussion of plants and animals observed, or expected to be present, at Camp Bowie. The extant plant communities appear to have been altered by a variety of land uses, including attempts to increase grass cover for livestock. Much of the area can be characterized as a Live Oak-Mesquite-Ashe Juniper community. Major tree and shrub species present include a variety of oaks, ashe juniper, mesquite, pecan, cedar elm, American elm, lotebush, and whitebush. Grasses, including Texas grama and buffalo grass, with a variety of cacti are also present. Major mammalian fauna include white-tailed deer, jackrabbit, and cottontail (Adjutant General's Department of Texas 1992; Nature Conservancy of Texas 1996; Texas Parks and Wildlife Department 1994).

\section{The Survey Areas}

The survey area consists of three parcels totaling approximately 200 acres (Figure 5). These areas had been previously surveyed (Wormser and Sullo-Prewitt 2001), but none were shovel tested during that effort. Parcel 1 is located on deep, Nukrum soils on an alluvial terrace that has a high probability of containing archaeological sites. The four previously recorded sites (41BR248, 41BR467, 41BR469, and 41BR471; Wormser and Sullo-Prewitt 2001) were also not shovel tested during their initial identification and recording.

Parcel 1 is located in the northeastern portion of Camp Bowie (Figures 4 and 5). This survey area is approximately 74 acres ( $~ 30 \mathrm{ha})$ in size. It is situated at the western margin of the Pecan Bayou floodplain adjacent to the Cretaceous upland ridge. The soils in Parcel 1 are primarily Nukrum, deep silty clay soils. This alluvial plain is subject to flooding and vertical sedimentary accretion. Parcel 1 is currently used as a tank range. The western two-thirds of this survey area have been impacted by road construction, heavy vehicular traffic, brush clearing, and firing range use. Parcel 1 is roughly triangular in shape and measures approximately $630 \mathrm{~m}$ from west to east on the southern boundary. The western margin is approximately $900 \mathrm{~m}$ long and the eastern side $620 \mathrm{~m}$ long. This relatively level survey parcel ranges in elevation from $1,300 \mathrm{ft}$ AMSL on the eastern side to less than $1,330 \mathrm{ft}$ (396-405 m AMsL) on the western side. Most of this parcel is situated between $1,300 \mathrm{ft}$ and less than 1,310 $\mathrm{ft}$ AMSL. During the survey, most of the ground surface was obscured by thick grass cover. Portions of the western half of this parcel have been extensively impacted by mechanical removal of mesquite trees and two large brush piles cover extensive areas. The eastern margin is sparsely wooded with very thick grass cover.

Parcel 2 is located in the southern portion of Camp Bowie (Figures 4 and 5) and is approximately 64 acres ( 26 ha) in area. This survey area is situated on the Cretaceous upland. It is mantled by Doudle-Real association thin, immature 


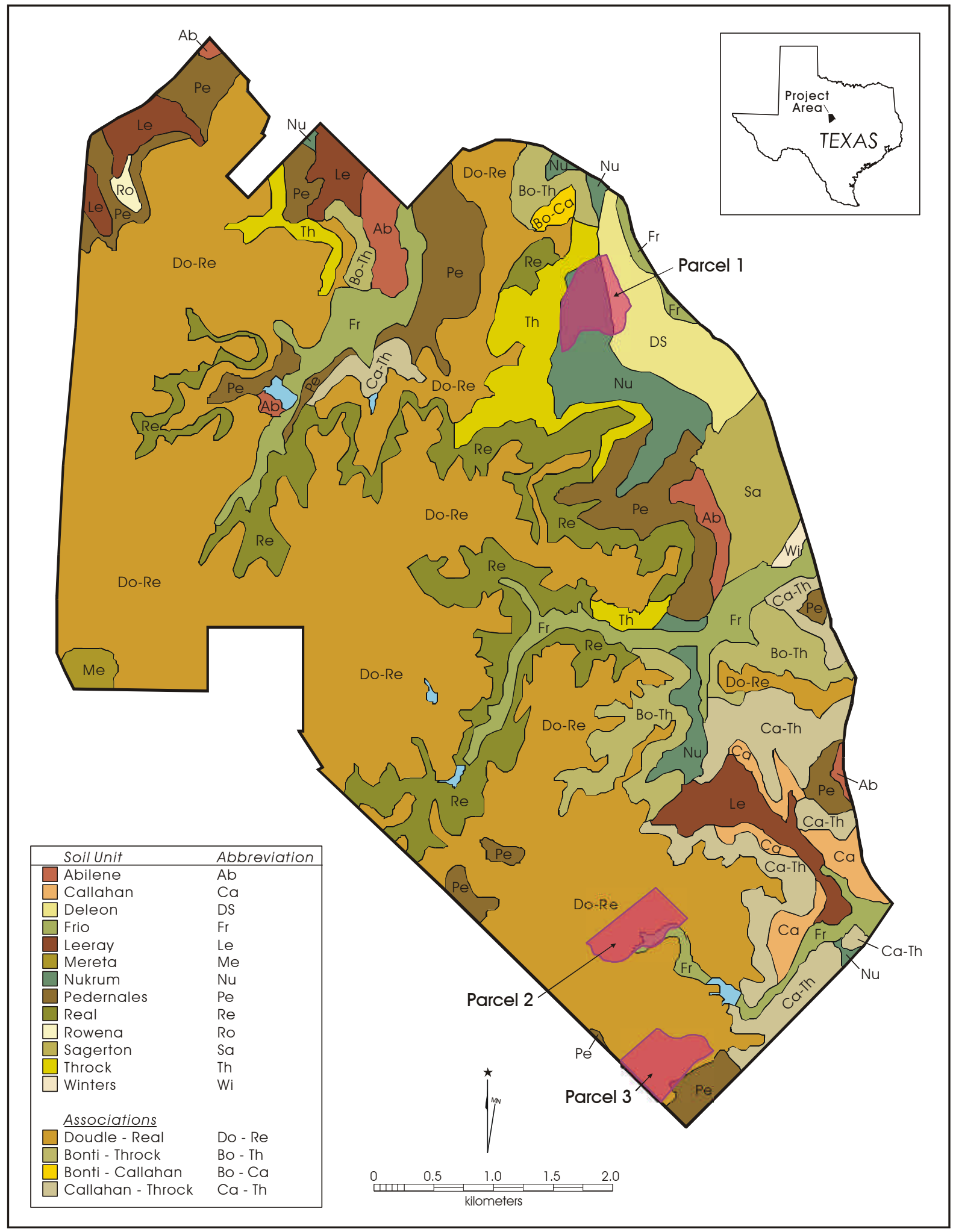

Figure 4. Soils on Camp Bowie with survey parcels identified. 


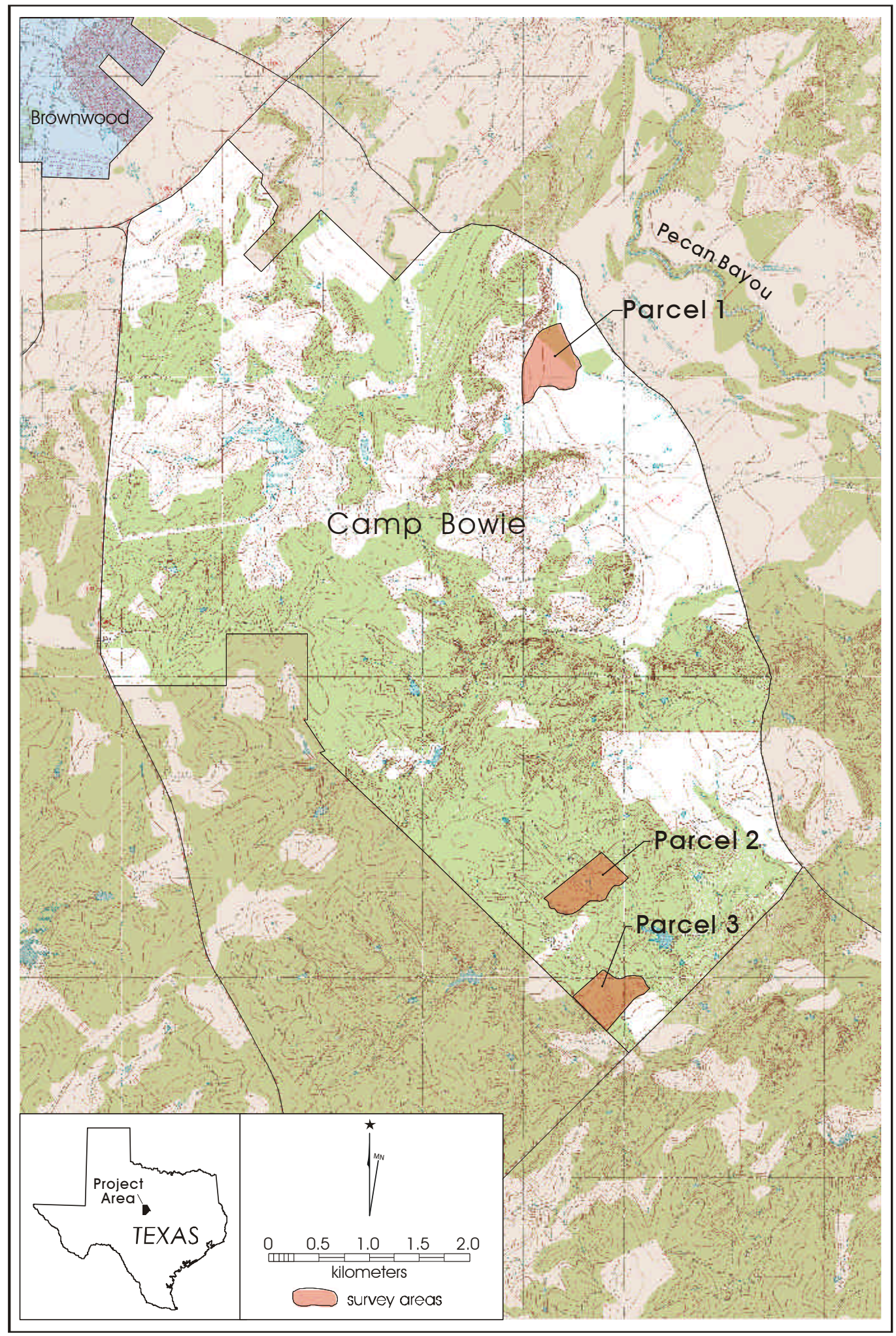

Figure 5. Locations of survey parcels within Camp Bowie. 
soils. This parcel is roughly rectangular and measures approximately $690 \mathrm{~m}$ southwest-northeast by $270-360 \mathrm{~m}$ northwest-southeast. The elevation of this unit ranges from $1,420-1,470 \mathrm{ft}$ AMSL (433-448 m). A seasonal stream forms the southeastern boundary of Parcel 2. The vegetation is broken woodland with many areas of open grass cover. Two heavily used two-track roadways are adjacent to this area, one just outside of the northwestern boundary and one crossing the northernmost corner of the survey area. An unused cleared roadway still scars the western end of Parcel 2. A heavily impacted area is present around a stock pond near the center of this parcel. One previously recorded site (41BR425) was reported within the survey unit (Wormser and Sullo-Prewitt 2001:100).

Parcel 3 is an area of approximately 62 acres ( 25 ha) located in the southwestern-most portion of Camp Bowie (Figures 4 and 5). It is on the Cretaceous plateau between approximately 1,410-1,455 ft AMSL (430-443 m). The entire survey unit is situated on the thin Doudle-Real association soils. This roughly rectangular survey area is bounded on the northeastern side by a roadway. It is approximately 380 $\mathrm{m}$ northwest-southeast by $390-600 \mathrm{~m}$ southwest-northeast. Much of the area is sparsely wooded with open areas of grass cover. The area southeast of Parcel 3 is a formerly plowed field and the adjacent margin of this unit has been plowed and impacted by construction of a stock pond. A two-track road runs along the western boundary of this unit parallel to the fenceline boundary of Camp Bowie. There is an additional unused roadway within $50-100 \mathrm{~m}$ east of this fenceline. 



\section{Chapter 3: Prehistoric Cultural Background and Previous Research on Camp Bowie}

This chapter provides an overview of the archaeological record for the Brown County area, along with a summary of previous research conducted on Camp Bowie. While a brief summary is provided of all prehistoric periods, the focus of the cultural background is on the Archaic and Late Prehistoric periods, the two time-frames represented by the archaeological material recovered during the current project. On the current project, no historic material was recovered within the survey parcels, and therefore the reader is referred to Wormser and Sullo-Prewitt (2001) and Leffler (2002) for detailed summaries of the historic period on Camp Bowie.

The Brown County/Camp Bowie area falls in the northwest corner of the Central Texas archaeological region (Collins 1995; Turner and Hester 1993). The major cultural periods defined for this region are briefly described below. Additional information can be found in Collins (1995) and Johnson and Goode (1994).

\section{Paleoindian}

The Paleoindian period marks the first appearance of humans in the New World, although the exact date of their arrival is unclear. Traditionally, the Paleoindian period is first marked by the appearance of Clovis points in North America, which -in turn- are replaced by Folsom points. The later Paleoindian period $(10,000-8000 \mathrm{BP})$ is characterized by a variety of dart point types, including Plainview, Dalton, Angostura, Scottsbluff, and Golondrina (Black 1989a, 1989b). Despite changes in these various projectile point types through time, their geographic range is widespread.

Artifacts, particularly projectile points, are often only isolated finds, though camp, lithic procurement, kill, cache, ritual and burial sites are known (Collins 1995). Early Paleoindian peoples have generally been conceptualized as hunter-gatherers ranging over wide areas in pursuit of now extinct megafauna, such as mammoth and Bison antiquus. This view of Paleoindian peoples, much like the dating of this period, is now being reassessed. While certainly exploiting Late Pleistocene megafauna, these peoples are perhaps better characterized as more generalized huntergatherers. Certainly by the later Paleoindian time-frame, after the extinction of these megafauna, the hunting aspect of subsistence shifted to exploitation of large herbivores like deer and Bison bison.

\section{Archaic}

The Archaic period can be broadly defined by changes in projectile point types, an increase in the number and types of sites (including burned rock hearths and middens), and by an increase in the variety of artifact styles, with many artifacts having more limited geographical distribution. While a number of finer subdivisions exist for the Archaic (e.g., Prewitt 1981; Weir 1976), this period can be broadly divided into the Early, Middle, and Late Archaic.

\section{Early Archaic}

Collins (1995:383) dates the Early Archaic from 8800 to 6000 BP in Central Texas with three divisions based on projectile point types, while Hester (1995:436-438) identifies the Early Archaic with Early Corner Notched and Early Basal Notched dart points roughly dating between 7950 to 4450 вр. The Early Archaic on the Southern Great Plains is approximated at 8000-5000 вP (Hofman 1989), although Johnson and Holliday (1986) offer more finegrained dates of $8500-6400$ BP for the Llano Estacado, based on data from the Lubbock Lake site. The extinction of large herds of megafauna and the changing climate at the beginning of the Holocene appears to have stimulated a behavioral change by the Prehistoric inhabitants of Texas. While the basic hunter-gatherer adaptation probably remained intact, an economic shift away from big game hunting was necessary. In general, more intensive exploitation of local resources in Central Texas, such as deer, fish, and plant bulbs is indicated by greater densities of ground stone artifacts, fire-cracked rock cooking features, and more specialized tools such as Clear Fork gouges and Guadalupe bifaces (Turner and Hester 1993:246, 256). Weir (1976) speculates that Early Archaic groups were small and highly mobile, an inference based on the fact that Early Archaic sites are thinly distributed and that diagnostic projectile point types are seen across a wide area, including most of Texas and northern Mexico. Hurt (1980) suggests that the decline in the number of bison on the plains forced the inhabitants to broaden their diets to pursue plants and animals which would produce the same amount of calories and protein with the same or slightly more effort expended. Story (1985) suggests that population densities were low during this period, and that groups consisted of related individuals in small bands with "few constraints on their 
mobility" (Story 1985:39). Their economy was based on diffuse utilization of a wide range of resources, especially such year-round resources as prickly pear and lechugilla, as well as rodents, rabbits, and deer (Story 1985:38).

\section{Middle Archaic}

Collins (1995:383) defines this intermediate interval of the Archaic as lasting from about 6000 to 4000 BP in Central Texas, but Hester (1995:438-441) suggests that the period between 4450 and 2350 вр more correctly reflects the Middle Archaic in South Texas. The Southern Plains Middle Archaic complex, as derived from changes in climate and subsistence, is recognized generally as the period between 5000-3000 BP (Hofman 1989:45-47), and more specifically as 6400-4500 BP on the Llano Estacado (Johnson and Holliday 1986:46). The Middle Archaic appears to have been a time of increased population, based on the large number of sites from this period in South and Central Texas (Story 1985:40; Weir 1976:125, 128). The reasons for this increase are not known, but the amelioration of a very dry period (Altithermal) during the Early Archaic is often seen as the prime mover (Story 1985:40). A wide variation in projectile point styles at the Jonas Terrace site suggests "a time of ethnic and cultural variety, as well as group movement and immigration" (Johnson 1995:285). Hurt (1980) posits that the quantity of diversified game animals on the Southern Great Plains decreased, and thus led to an intensified, less broad diet. On the South Texas Plain, exploitation of widely scattered, year-round resources such as prickly pear continued (Campbell and Campbell 1981:1315), as did hunting deer and rabbit. However, a shift to concentrated, seasonal nut harvests in the riverine environments of the Balcones Escarpment seems to have occurred (Black 1989a, 1989b). Weir (1976) believes that an expansion of oak on the Edwards Plateau and Balcones Escarpment led to intensive plant gathering and acorn processing. He also believes that the widely scattered bands prevalent in the Early Archaic now began to coalesce, at least during the acorn-gathering season, into larger groups who shared the intensive work of gathering and processing the acorn harvest (Weir 1976:126). Many researchers believe burned rock middens are a result of this endeavor (Creel 1986; Prewitt 1991; Weir 1976). Other investigators doubt this conclusion (Black et al. 1997; Goode 1991), but the exact processes that formed burned rock middens are still a matter of controversy (see Hester 1991; Leach and Bousman 2001[1998]).
The common presence of deer remains in some burned rock middens encourages the view that deer processing took place at burned rock midden sites (Black and McGraw 1985:278; Nickels et al. 2001[1998]; Weir 1976:125). Bison bone is encountered in archaeological sites in Central and South Texas, at least occasionally, during all but the earliest part of the Middle Archaic (Dillehay 1974). There has been a tendency to equate presence of burned rock middens with absence of bison (Prewitt 1981); however, examinations of several recent faunal reports show that after about $4500 \mathrm{BP}$ bison and burned rock middens are contemporaneous, though not at the same sites, at least in the southern Edwards Plateau and northern South Texas Plain (Meissner 1993).

\section{Late Archaic}

Collins (1995:384) dates the final interval of the Archaic in Central Texas to approximately 4000-800 BP. Hester believes the Late Archaic in South Texas may be better defined as between 2350-1250 BP, while Hofman's (1989:45) synthesis of these data places the Late Archaic on the Southern Plains as 3000-2000 BP, and possibly later. Johnson and Holliday (1986:46) specify 4500-2000 вР as the Late Archaic period on the Llano Estacado. Some researchers believe populations increased throughout the Late Archaic (Prewitt 1985), while others feel populations remained the same or fell during this period (Black 1989a). Prewitt (1981:80-81) asserts that the accumulation of burned rock middens nearly ceased during the course of this period; however, excavations at a number of sites (e.g., Houk and Lohse 1993:193-248; Johnson 1995) provide evidence that large cooking features up to 15 meters in diameter were still very much in use. Subsistence is assumed to have become less specialized during the Late Archaic (Black 1989a:30). Hurt (1980) asserts that bison began returning to the Southern Great Plains area, and we see an increase in intensive processing of bison, as well as mussel shells during the Late Archaic. However, by about 1450 BP, bison had again disappeared (Dillehay 1974).

The proliferation of distinguishable human cemeteries has been attributed to this period, with the earliest occurrences dating to the South Texas Middle Archaic (Hester 1995:439440). At Loma Sandia, these date between ca. 2550 and 2750 BP (Taylor and Highley 1995). Story (1985:44-45) believes the presence of cemeteries at sites such as Ernest Witte (Hall 1981), Hitzfelder Cave (Givens 1968), and Olmos Dam (Lukowski 1988) indicates that Late Archaic 
populations in Central and South Texas were increasing and becoming more territorial.

Late Archaic points tend to be much smaller than Middle Archaic points. The most common are Ensor and Frio types (Turner and Hester 1993:114, 122), both of which are short, triangular points with side notches. The Frio point type also has a notched base (Turner and Hester 1993:122). And in terms of Late Archaic ceramics, although inhabitants of the South Texas Plain near Brownsville and Rockport had begun to make pottery by about $1750 \mathrm{BP}$, the northern part of the plain remained "pre-ceramic" until 1,000 years later (Story 1985:45-47).

A late subperiod or interval of the Late Archaic is frequently referred to as the Terminal Archaic or Transitional Archaic. Weir (1976) defines the Terminal Archaic as 1650$1150 \mathrm{BP}$, while Turner and Hester (1993) cite data placing the Transitional Archaic as 2250-1250 BP. Although Hester may lump current data into a Late Archaic period, he cautions that more evidence will likely result in what may be termed as a "Terminal Archaic" period during the latter part of the Late Archaic in South Texas. This Terminal Archaic period is represented by diagnostics such as Ensor, Frio, and Matamoras points which appear to overlap the Late Archaic and the subsequent Late Prehistoric period (Hester 1995:442). Weir (1976) believes this marked a transition period to localized area sites, a disappearance of burned rock middens and bison, and a reappearance of highly mobile hunters and gatherers. Others (Black and McGraw 1985; Skelton 1977) argue that in some locations burned rock middens did not disappear and sites were more intensely occupied during the Transitional Archaic period. During the Early Neo-Indian period on the Southern Great Plains (ca. 950-1450 вг), Hurt (1980) presents evidence for a decrease in bison processing. This decrease is consistent with Dillehay's (1974) contention that there were fewer bison available in the area due to climatic changes.

\section{Late Prehistoric}

The term Late Prehistoric is commonly used to designate the period following the Late Archaic in Central and South Texas. Collins (1995:385) recognizes that the commonly used date of 1200 BP for the end of the Archaic and beginning of the Late Prehistoric in Central Texas is arbitrary, and Hester (1995:442) acknowledges the problematic issue of selected tools appearing at both Late Archaic and Late
Prehistoric sites. A series of distinctive traits marks the shift from the Archaic to the Late Prehistoric period, including the technological shift to the bow and arrow and the introduction of pottery to Central Texas and the northern South Texas Plain (Black 1989a:32; Story 1985:45-47). Two complexes following the Late Archaic in the Southern Great Plains region are the Plains Woodland from about 20001150 вP, and the Plains Village from 1150-450 вр (Hofman 1989:61-90). Most researchers agree the early Late Prehistoric period was a time of population decrease (Black 1989a:32). Though small burned rock middens associated with Scallorn and Edwards points have been found (Goode 1991:71; Houk and Lohse 1993:193-248), most researchers argue that they are rare. Settlement shifts into rockshelters such as Scorpion Cave in Medina County (Highley et al. 1978) and Classen Rockshelter in northern Bexar County (Fox and Fox 1967) have been noted (Skinner 1981). Cemeteries from this period often reveal evidence of conflict (Black 1989a:32).

Beginning rather abruptly at about $650 \mathrm{BP}$, a shift in technology occurred. This shift is characterized by the introduction of blade technology, the first ceramics in Central Texas (bone-tempered plainwares), the appearance of Perdiz arrow points, and alternately beveled bifaces (Black 1989a:32; Huebner 1991:346). Prewitt (1985) suggests this technology encroached from north-central Texas. Patterson (1988), however, notes the Perdiz point was first seen in southeast Texas by about $1350 \mathrm{BP}$, and was introduced to the west some 600-700 years later. Hester (1995:444) recognizes this phase as the "best documented Late Prehistoric pattern" throughout South Texas, with dates ranging between ca. $650 / 700$ to $300 / 350 \mathrm{BP}$.

Steele and Assad Hunter (1986) argue for the occurrence of a distinct change in diet between the Late Archaic and the Late Prehistoric components in two sites in the Choke Canyon Reservoir area in South Texas. Analysis of the number of identified specimens (NISP) shows a marked increase in artiodactyl elements during the late Late Prehistoric, an increase largely due to the addition of bison to the "menu" (Steele and Assad Hunter 1986:468). Huebner (1991) suggests that the sudden return of bison to South and Central Texas resulted from a more xeric climate in the plains north of Texas, and increased grass in the CrossTimbers and Post Oak Savannah in north-central Texas, forming a "bison corridor" into the South Texas Plain along the eastern edge of the Edwards Plateau (Huebner 1991:354355). Sites from this period frequently have associated bison (Black 1986; Black and McGraw 1985; Prewitt 1974). 


\section{Previous Research in the Camp Bowie Area}

A review of archaeological literature for the Camp Bowie area produced limited results. Only a handful of excavation projects have been conducted, and with the exception of the two recent surveys of Camp Bowie (Mauldin and Broehm 2001; Wormser and Sullo-Prewitt 2001), few small surveys have been carried out. Archaeological research in the Brown County area dates to the early portion of the twentieth century with the excavations of Pearce at the burned rock midden site of Pitman (41BR3) conducted in 1919 (Campbell 1952; Kirby and Moir 1976). Pearce trenched two middens, both of which appeared to have been ring- or crescent-shaped. While both contained large quantities of charcoal and firecracked limestone and a few fragments of bone and shell, it appears that neither midden contained any artifacts (Campbell 1952).

From the early work of Pearce in 1919 until the 1970s, no substantial archaeological investigations seem to have occurred in Brown County. Beginning in the early 1970s, a series of survey projects were conducted, including two by archaeologists from Texas A\&M University (Shafer et al. 1975a, 1975b), a survey of Cordell and Camp Bowie City Park Sites in Brownwood completed by Kegley and Black (1978), a survey by Southern Methodist University along Pecan Bayou north of Brownwood (Kirby and Moir 1976), and a survey by Prewitt and Associates for the City of Brownwood sanitary landfill site (Prikryl 1983). All of these surveys consistently recorded lithic scatters and burned rock features, including the presence of large ring and domeshaped middens.

In 1979, the Texas Archeological Society Field School was located near Cross Cut in the far northwest corner of Brown County. Gearhart and Voellinger (1986) report that work was conducted on both ring and mound burned rock middens. In addition, Howard (1991) references excavations of three burned rock midden sites in Brown County (41BR72, 41BR105, and 41BR110). However, additional information on these projects could not be located.

In 1986, Espey, Huston \& Associates conducted testing at 41BR313 and 41BR314 (Gearhart and Voellinger 1986), two sites originally documented by Prikryl (1983) as a result of the sanitary landfill survey mentioned previously. A total of four 1 x 1-m units were excavated at these two sites. Testing did not reveal stratified deposits, and no additional work was conducted.
Prior to the 1993-1997 inventory survey of Camp Bowie (Wormser and Sullo-Prewitt 2001), little systematic work had been conducted on the installation. A portion of the Brownwood Laterals Watershed survey, conducted by Texas A\&M University in 1975 (Shafer et al. 1975b), was acquired by Texas Army National Guard (TXANG). Three sites (41BR65, 41BR66, and 41BR68) were incorporated into Camp Bowie as a result of that acquisition. In addition, Wormser and Sullo-Prewitt (2001:13) reference small-scale survey work on the camp conducted by Briggs (1992), as well as two TXANG staff reports (Wormser et al. 1994, 1997).

TXANG archaeologists conducted an inventory survey of 98.5 percent of the total Camp Bowie area between 1993 and 1997 (Wormser and Sullo-Prewitt 2001). A total of 186 prehistoric and historic sites were recorded. A variety of prehistoric site types were identified, including open campsites, lithic workshops, lithic procurement sites, and burned rock midden sites. During this survey, an area of 90 acres was under cultivation and not investigated at the time. Archaeological survey of the 90 -acre area was performed in 2001 (Mauldin and Broehm 2001) and three prehistoric sites (41BR499, 41BR500, and 41BR501) were identified. Possible Late Archaic affiliation of 41BR500 is suggested from a single point and this site was recommended for additional testing. The other two Late Prehistoric sites were not considered significant. 


\section{Chapter 4: Methodology}

\section{Field Methods}

Consistent with the Specification for Services, standard methods of pedestrian survey and shovel testing were performed during the archaeological survey at Camp Bowie. Fieldwork was performed by a crew of four archaeologists from CAR during October and November 2001. Survey examined ground surfaces along transects spaced approximately $30 \mathrm{~m}$ apart. Specific placement of shovel tests along these transects was judgmental. There was no stratification to sampling of areas within each parcel. The three survey parcels were small enough that this form of sampling resulted in relatively even coverage within each parcel and is considered to be a representative spatial examination of the subsurface in these areas. Each shovel test measured $30 \times 30 \mathrm{~cm}$ and was excavated in $10-\mathrm{cm}$ arbitrary levels referenced to the current ground surface. All shovel tests were dug to $60 \mathrm{~cm}$ below the ground surface, if possible. The location of each shovel test was recorded using a Trimble Geo Explorer II GPS unit. A total of 122 shovel tests was excavated within the survey parcels. Fortysix were excavated in Parcel 1, 33 in Parcel 2, and 43 shovel tests were excavated in Parcel 3. An additional seven shovel tests were excavated on 41BR522, just on the outer margin of survey Parcel 1. All soils and sediments excavated were screened through 1/4-inch mesh hardware cloth. Standard shovel test forms were used to record observations on soil and sediment qualities, materials recovered, and other pertinent information. Black and white photographs and color slides were taken of all archaeological sites examined.

A sediment susceptibility sample was collected from the first and final excavation level in every shovel test from survey parcels. Sediment susceptibility, or magnetic susceptibility, samples were collected from every level in shovel tests dug on the archaeological sites. Magnetic susceptibility (MS) of sediments can be a useful analytic tool for identifying past human activity. This method is especially productive in soils that do not have readily apparent stratigraphy and where the nature of potential palimpsest deposits is ambiguous. Signature values from MS analyses are related to the organic content of sediments (Collins et al. 1994; McClean and Kean 1993; Singer and Fine 1989) and the decay of those materials (Reynolds and King 1995). Variance in values produced from analysis of samples provides relative information about the comparative differences in past organic content of adjacent sampled areas of a site. This analysis can identify vertical and horizontal areas that have experienced organic enrichment. This sampling and analysis has been productively used in previous investigations at Camp Bowie (Mauldin and Broehm 2001).

For the purpose of this survey, sites were defined as locations having at least five artifacts within a $30-\mathrm{m}^{2}$ area, or as a location containing a single cultural feature such as a hearth. All other artifacts were classified as isolated occurrences. When an artifact concentration was identified as a site, crew members established a datum consisting of a length of rebar hammered into the ground at the site's center. Using GPS units, CAR surveyors took readings from the site datum and from points along the perimeter to define the estimated site boundary. A standardized form containing observations concerning types and degree of site disturbance, vegetation, estimated artifact counts by category (i.e., debitage, bifaces, unifaces), and observations on features was completed. Diagnostic artifacts were collected when found, and their location recorded with a GPS unit. In addition, sketch maps, showing site boundaries, datum locations, shovel tests, collected items, features, areas of high artifact density, and physical features on the landscape, were recorded. Archival quality 35-mm black-and-white prints were made of all sites and artifacts where appropriate. Texas site forms were prepared for all new sites encountered on the project.

\section{Laboratory Methods}

All cultural material collected during the survey was prepared in accordance with federal regulation 36 CFR, part 79, and in accordance with current guidelines of the Texas Archeological Research Laboratory (TARL). Artifacts processed in the laboratory at CAR were washed, air-dried, sorted into appropriate categories (e.g., debitage, projectile points, bifaces, unifaces, cores), analyzed, and stored in archival-quality bags. Acid-free labels were placed in all artifact bags. Each label contained a provenience and corresponding lot number. Tools were labeled with permanent ink and covered by a clear coat of B72 acryloid. In addition, a small sample of unmodified debitage from each lot was labeled with the site and lot number. All artifacts were stored in acid-free boxes. Boxes were labeled with standard labels. Field notes, forms, and drawings were 
placed in acid-free, labeled file folders. Photographs, slides, and negatives were placed in archival-quality sleeves. All materials were stored in acid-free boxes. Documents and forms were printed on acid-free paper. Upon completion of the project, all cultural materials and records will be sent to TARL for permanent storage.

Sediment susceptibility samples have not been processed from this survey and testing work. The previously identified sites that were tested during this effort had only thin soils and lowdensity subsurface artifact recovery, with 41BR522 serving as the only exception, no new archaeological sites were identified within the survey parcels. Magnetic susceptibility of the sediment samples was not performed because recovery provided few comparative data for their interpretation. These sediment susceptibility samples have been curated for potential future analyses. 


\section{Chapter 5: Survey Results}

\section{Parcel 1}

Pedestrian survey and shovel testing of the largest parcel ( 74 acres) and of the four previously recorded archaeological sites was performed October 29-November 2, 2001. A total of 46 shovel tests (ST) was placed in survey Parcel 1 (Figure 6). This area is entirely within the floodplain deposits of Pecan Bayou that are in deep Nukrum silty clay soils. This is the portion of the alluvial plain farthest from the modern channel, adjacent to uplands of Cretaceous formation mantled by thin Throck soils. Several shovel tests were placed outside of the survey parcel because of the difficulty identifying the boundaries of this unit during fieldwork (T3-ST13, T3-ST14, T4-ST12, T4-ST13, T4ST14, and T5-ST9). The ephemeral creek on the southeastern portion of Parcel 1 is expressed as a very shallow, heavily vegetated depression. There has been extensive heavy equipment clearing of trees along the western boundary of Parcel 1. A single shovel test (T4-ST1) was placed outside of the survey area on this western side because of the presence of a single surface artifact. Four shovel tests were positive for subsurface materials (T4-ST9, T4-ST10, T4-ST13, and T7-ST1). Two shovel tests contained lithics from apparently disturbed soil contexts (T4ST9 and T4-ST10). More rubified sediments and localized evidence of mechanical blading indicate previous disturbance of this location, therefore these are considered isolated finds. A burned rock midden (41BR522) was identified on the northwestern margin of this survey parcel.
Much of this parcel has been highly disturbed by heavy equipment clearing of brush, construction of roads, and use of the area as a firing range. Artifacts and bone recovered from shovel tests in this area are presented in Table 1.

The two pieces of bone from T4-ST13 refit and are a single, deer-sized, long bone diaphyseal fragment. These bone fragments were recovered in screened sediments from separate levels. It is uncertain whether the two pieces derive from different levels or their provenience has become mixed from the imprecise control offered by $30 \times 30-\mathrm{cm}$ shovel tests. The piece from Level 3 (Lot \#2-2) exhibits a portion of a fresh break along one side. Dry breaks are evident on all other margins.

\section{$41 \mathrm{BR} 522$}

41BR522 is a burned rock midden with a small associated area of artifact debris on the downslope side of the feature. The site is located just outside of the northwestern boundary of Parcel 1. Because the margin of this survey parcel is along the contact of the floodplain with the uplands, and its precise location was difficult to determine, this site was recorded during the fieldwork. The site is situated at the lower slope margin of an upland area as it meets the broad, flat alluvial plain of Pecan Bayou and its tributaries (Figures 6 and 7). This upland area is part of the Cretaceous plateau made of Travis Peak formation conglomerates, sandstone, and

Table 1. Artifacts recovered from Parcel 1

\begin{tabular}{|c|c|c|l|l|}
\hline Shovel Test & $\begin{array}{c}\text { Maximum } \\
\text { Depth* }\end{array}$ & $\begin{array}{c}\text { Levels with Artifacts } \\
\text { Level \# (depth*) }\end{array}$ & $\begin{array}{c}\text { Artifacts Collected } \\
\text { Kind (\#) }\end{array}$ & \multicolumn{1}{|c|}{ Comments } \\
\hline surface & 0 & surface & biface fragment (1) & west of Parcel 1 boundary \\
\hline T4-ST9 & $60 \mathrm{~cm}$ & $5(40-50 \mathrm{~cm})$ & flake $(1)$ & midsection fragment \\
\cline { 3 - 5 } & & $6(50-60 \mathrm{~cm})$ & flake $(1)$ & complete \\
\hline T4-ST10 & $60 \mathrm{~cm}$ & $3(20-30 \mathrm{~cm})$ & flakes $(2)$ & 1 complete; 1 distal fragment \\
\hline T4-ST13 & $60 \mathrm{~cm}$ & $3(20-30 \mathrm{~cm})$ & bone $(1)$ & refits with bone from lev. 4 \\
\cline { 3 - 5 } & & $4(30-40 \mathrm{~cm})$ & bone $(1)$ & distal fragment \\
\hline T7-ST1 & $60 \mathrm{~cm}$ & $5(40-50 \mathrm{~cm})$ & flake $(1)$ & \\
\hline
\end{tabular}

* centimeters below modern ground surface 


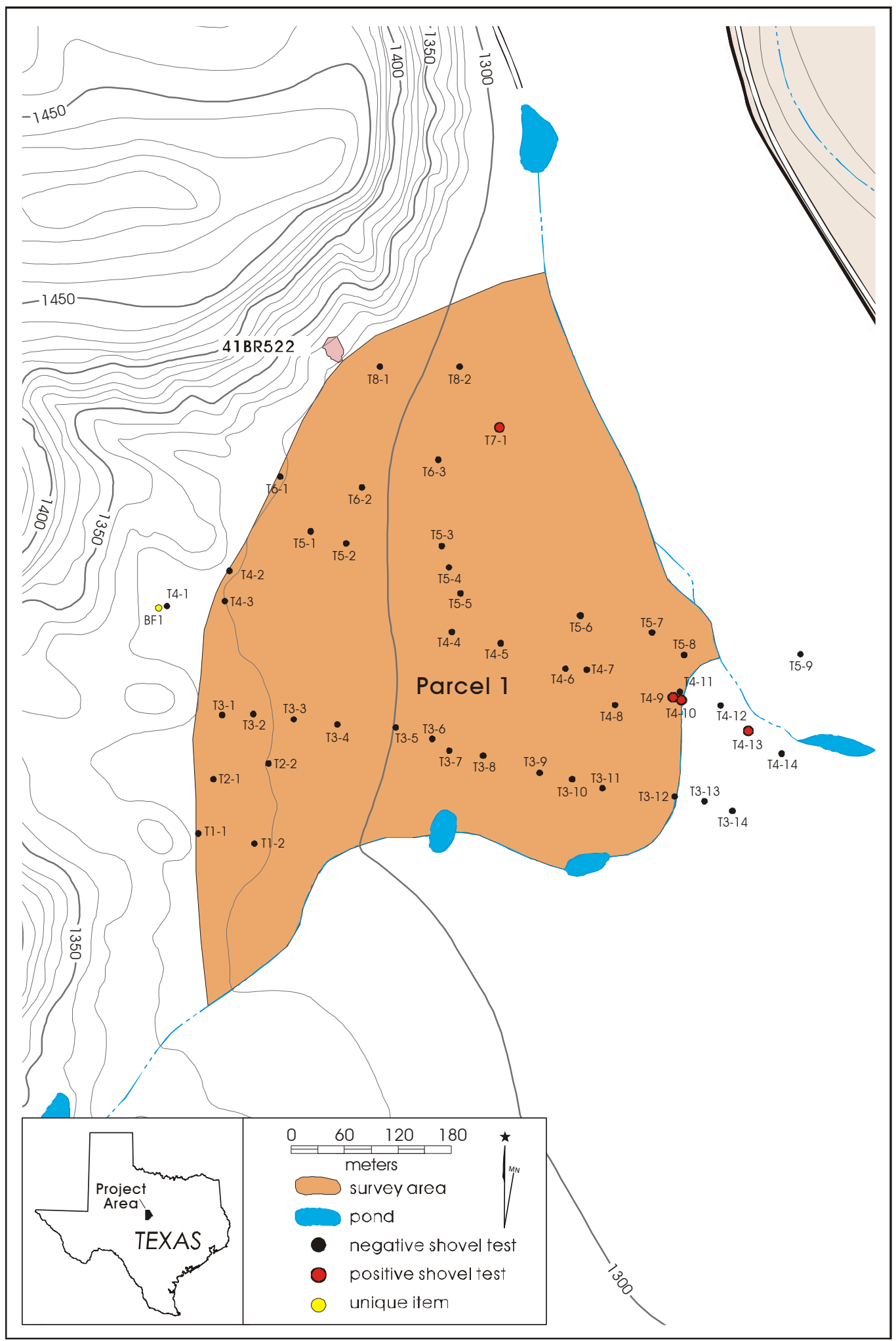

Figure 6. Location of site $41 B R 522$ and shovel tests on Parcel 1. 


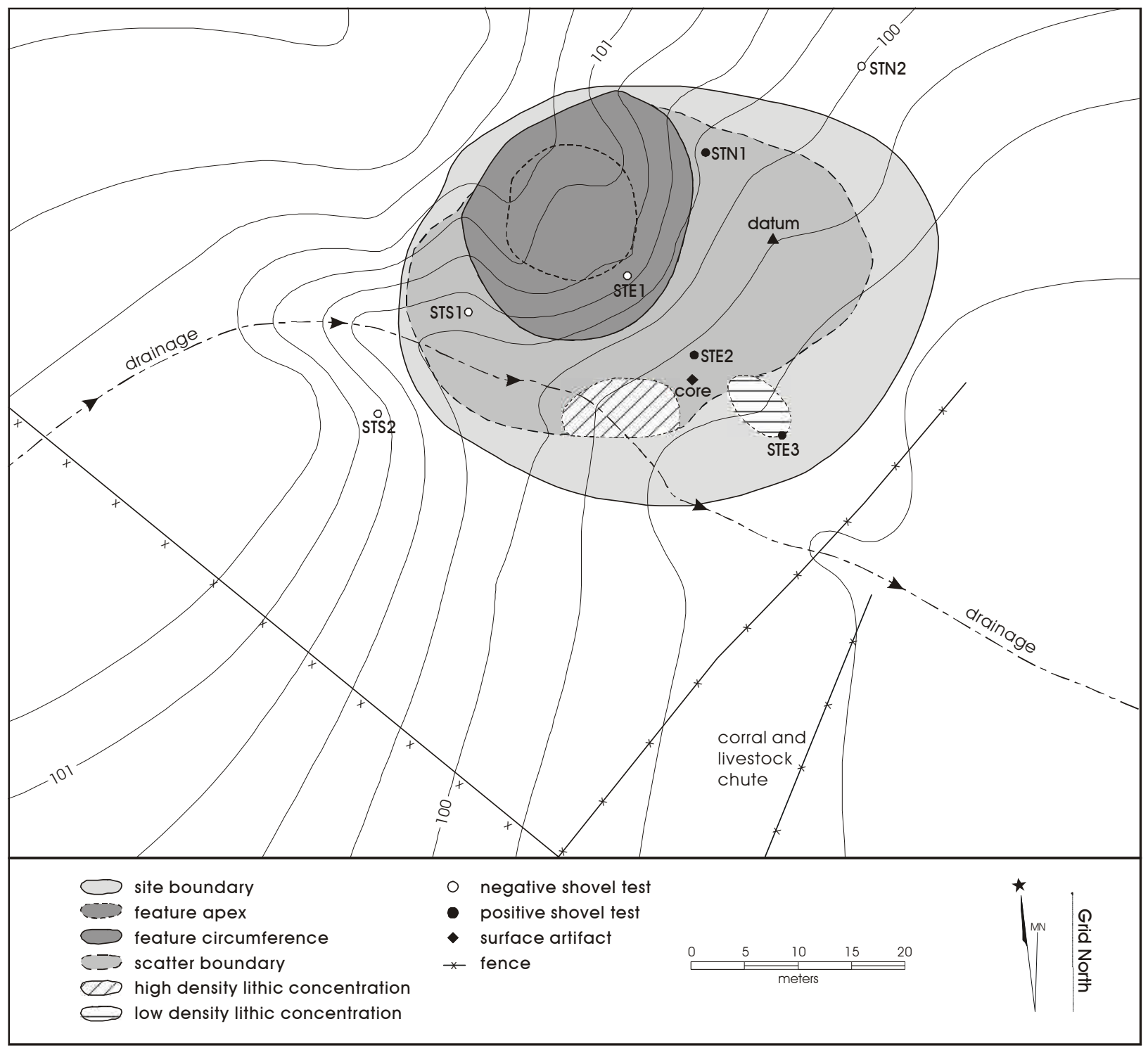

Figure 7. Site 41BR522.

limestone. 41BR522 is located at the southeastern margin of alluvial fan deposits of colluvial material and the western boundary of the recent Pecan Bayou alluvial plain. The site is situated at the margin of the Throck upland soils and the Nukrum soils of the alluvial plain. The upland area is the source of rock used in this feature. Ground surface visibility during site recording was greater than 60 percent. There is a low-density surface scatter of lithics adjacent to the feature. No evidence of additional features was identified during site recording. This burned rock midden is very near another site with a burned rock midden feature (41BR493) located approximately $250 \mathrm{~m}$ north on the older, upland surface.
Other nearby isolated, or small, burned rock midden sites are 41BR248 and 41BR392 (see Map Supplement). Several larger sites with one or two midden features present include 41BR228, 41BR245, 41BR246, 41BR250, 41BR253, and 41BR415.

The maximum dimensions of the midden are approximately $14 \mathrm{~m}$ north-south by $15 \mathrm{~m}$ east-west and it stands slightly more than $1 \mathrm{~m}$ high (Figure 7). There is a pronounced central depression to this midden. Six shovel tests were placed around the burned rock midden feature. One additional shovel test (ST E-1) was placed on the midden deposit and 
terminated at $20 \mathrm{~cm}$ below surface ( $\mathrm{cm} \mathrm{bs}$ ). No attempt was made to excavate this test unit deeply into the midden. The small size of the shovel tests makes deeper excavation into the dense fire-cracked rock logistically difficult, offers poor vertical control, and is a problematic sample for comparison with standard $1 \times 1-\mathrm{m}$ recovery units. Three of the shovel tests were positive (ST E-2, ST E-3, and ST N-1), the results are presented in Table 2.

The single shovel test in the midden (ST E-1) identified dark, charcoal stained deposits. No further disturbance of the midden was considered useful. Five shovel tests were excavated to a depth of $60 \mathrm{~cm}$ bs. The sixth unit was terminated because of the density of colluvial rock at $50 \mathrm{~cm}$ bs. Sediment susceptibility samples were collected from every excavation level in each of the shovel test units. The three positive shovel tests contained chipped lithics, two produced lithics as deep as $10-30 \mathrm{~cm}$ bs. A biface tip and one flake were recovered from ST E-3 at approximately $20-30 \mathrm{~cm}$ bs. The biface fragment is the distal portion of the thin blade of a projectile point. This piece exhibits serration of both edges from well-controlled pressure flaking. This finely made, serrated point is missing all of the proximal portion and cannot be typed. There is a light scatter of lithics on the flat area to the south of the midden. Some mussel shell was associated with the lithics, but it is unknown if this shell is cultural in origin. The area containing archaeological debris does not extend far from the midden as artifacts were identified only within $5-8 \mathrm{~m}$ from the margin of the burned rock midden. The upslope side north of the midden had no artifacts outside of this feature.

Fire-cracked rock was not collected from the shovel tests. The amount encountered in each unit and the size of the pieces, however, were recorded although no weight data were collected during this field effort. Much of the firecracked rock recovered from the single unit excavated in the midden (ST E-1) was small, $<2 \mathrm{~cm}$ in maximum dimension. Numerically, smaller fragments of fire-cracked rock (the majority were $<4 \mathrm{~cm}$ in maximum dimension) were the most commonly recovered artifacts from shovel tests. The mussel shell from ST N-1 is currently in three pieces that refit. This valve was damaged during excavation but clearly represents a single, nearly complete shell. This is the dorsal portion of a left valve. No species identification has been made on this specimen, and there is no evidence of burning on this shell or other indicators of human modification. Additional mussel shell was also present in the surface lithic concentration south of the midden. Two charcoal samples were collected from outside of the midden (ST N-1), and although their context is questionable, they may be useful for wood species identification.

Table 2. Results of shovel tests at 41BR522

\begin{tabular}{|c|c|c|c|c|}
\hline Shovel Test & $\begin{array}{c}\text { Maximum } \\
\text { Depth* }\end{array}$ & $\begin{array}{c}\text { Levels with Artifacts } \\
\text { Level \# (depth*) }\end{array}$ & $\begin{array}{l}\text { Artifacts Collected } \\
\text { Kind (\#) }\end{array}$ & $\begin{array}{c}\text { Fire-cracked Rock } \\
(\text { not collected })\end{array}$ \\
\hline mapped & 0 & surface & unidirectional core (1) & \\
\hline \multirow[t]{2}{*}{$\mathrm{E}-1$} & \multirow[t]{2}{*}{$20 \mathrm{~cm}$} & $1(0-10 \mathrm{~cm})$ & 0 & $>150$ \\
\hline & & $2(10-20 \mathrm{~cm})$ & 0 & $>150$ \\
\hline \multirow[t]{2}{*}{ E-2 } & \multirow[t]{2}{*}{$60 \mathrm{~cm}$} & $1(0-10 \mathrm{~cm})$ & flakes (2); angular debris (1) & 0 \\
\hline & & $2(10-20 \mathrm{~cm})$ & flakes (2) & $1(2-5 \mathrm{~cm})$ \\
\hline \multirow[t]{3}{*}{ E-3 } & \multirow[t]{3}{*}{$60 \mathrm{~cm}$} & $1(0-10 \mathrm{~cm})$ & 0 & $2(2-5 \mathrm{~cm})$ \\
\hline & & $2(10-20 \mathrm{~cm})$ & 0 & $2(1=2-5 \mathrm{~cm}, 1=>10 \mathrm{~cm})$ \\
\hline & & $3(20-30 \mathrm{~cm})$ & flake (1); projectile point (1) & \\
\hline \multirow[t]{5}{*}{$\mathrm{N}-1$} & \multirow[t]{5}{*}{$50 \mathrm{~cm}$} & surface & 0 & $4(\sim 5 \mathrm{~cm})$ \\
\hline & & $1(0-10 \mathrm{~cm})$ & debitage (1) & 84 \\
\hline & & $2(10-20 \mathrm{~cm})$ & 0 & 20 \\
\hline & & $3(20-30 \mathrm{~cm})$ & charcoal (1); mussel shell (3) & 14 \\
\hline & & $4(30-40 \mathrm{~cm})$ & $\operatorname{charcoal}(1)$ & 4 \\
\hline $\mathrm{N}-2$ & $60 \mathrm{~cm}$ & 0 & 0 & 0 \\
\hline \multirow[t]{3}{*}{ S-1 } & \multirow[t]{3}{*}{$60 \mathrm{~cm}$} & $1(0-10 \mathrm{~cm})$ & 0 & $\sim 100$ \\
\hline & & $2(10-20 \mathrm{~cm})$ & 0 & $\sim 32$ \\
\hline & & $3(20-30 \mathrm{~cm})$ & 0 & 20 \\
\hline S-2 & $60 \mathrm{~cm}$ & 0 & 0 & 0 \\
\hline
\end{tabular}

* centimeters below modern ground surface 
On-site disturbances appear to be minimal. Despite the presence of a nearby corral and livestock chute, there are no visible indicators that this recent feature has impacted any archaeological deposits. There is a shallow, incised drainage along the southwestern side of the midden, but few artifacts were visible in this ephemeral drainage and it has not affected the midden feature. This midden appears to have been minimally disturbed following use. There is some colluvial and alluvial redeposition of rock from the midden on the southwestern (maximally $5 \mathrm{~m}$ ), southern $(4 \mathrm{~m})$, and especially southeastern side $(6 \mathrm{~m})$ of the midden. The area containing artifacts adjacent to the feature is not extensive. These qualities provide no suggestion of multiple-use events associated with this location and strongly suggest a single occupation episode. Shovel testing identified good-toexcellent potential for subsurface artifact deposits outside of the earth oven feature.

The preliminary examination indicates that this site should receive additional testing to determine its potential eligibility as a State Archeological Landmark (SAL) or National Register of Historic Places (NRHP) property. The strong likelihood that this is a single component site provides a unique opportunity. At larger sites, it is unclear how a burned rock feature may be associated with other portions of a site. It can be considered a central component to adjunct activities performed away from the feature, or it could represent a site use unrelated to the other archaeological material around the feature. If this feature is a relatively isolated event, it can provide a critical view of the kinds of debris and patterning uniquely associated with feature use. Excavation of additional shovel tests and several $1 \times 1-\mathrm{m}$ units are strongly recommended for this site.

Except for the recommendations of protection, avoidance, and additional testing of 41BR522 discussed above, survey and testing of the remainder of Parcel 1 did not produce any evidence of archaeological resources that would qualify as SAL or NRHP eligible. Based on this assessment, normal proposed uses of this area may proceed without further consultation with THC. It should be noted that Parcel 1 is located on floodplain deposits of Pecan Bayou and proposed activities or improvements that extend below the depth of shovel testing may encounter more deeply buried archaeological remains. It is recommended that any significant and deep excavation activities in this area involve archaeological monitoring of this location.

\section{Parcel 2}

Pedestrian examination and shovel test survey was conducted on Parcel 2 ( 64 acres) during November 17-18, 2001. Thirty-three shovel tests were excavated within this area and no subsurface artifacts were recovered from these units (Figure 8). Four isolated artifacts were recovered from surface contexts within this parcel and all of these are biface fragments. These artifacts were not associated with other surface artifacts nor did they appear to indicate any subsurface archaeological sites.

A previously recorded archaeological site, 41BR425, was reported to be within this survey parcel. An attempt to relocate this site, re-record it, and shovel test the location was not successful. There is a strong likelihood that the site has been mislocated to the north of an area with an ambiguous archaeological manifestation. It also is possible that because this site was previously defined only from its surface artifacts, one core and seven flakes (Wormser and Sullo-Prewitt 2001:100), that there is no subsurface component to this ephemeral presence. The mapped location of this site is very heavily vegetated with grass and sparse oaks and surface visibility is less than five percent. The area south of the previously identified location of 41BR425 has greater surface visibility $(>40 \%)$. The description of this site and its identification on the basis of apparent surface artifacts (Wormser and Sullo-Prewitt 2001:100) more closely resemble an area approximately $60 \mathrm{~m}$ southeast of the southeastern margin of the plotted location of 41BR425. Because re-evaluation of this site was not part of this research design and budget, systematic shovel testing beyond the survey work was not performed. This investigation found no subsurface archaeological material associated with the area where the site was plotted nor the alternative location matching its description. A single surface artifact (IF3) was the only evidence of prehistoric activity in this vicinity. Shovel test intervals were slightly adjusted to place them adjacent to the isolated surface biface (IF3) and on potentially more intact soils. Based on Wormser and SulloPrewitt's site description (2001:100) and the presence of an isolated surface biface (IF3), the location of 41BR425 has been updated on the TexSite form to this location south of its previously plotted position. There was a relatively high density of naturally fractured chert visible on this slightly eroding terrace margin. It is likely that the designation of this site as a "lithic workshop" (Wormser and Sullo-Prewitt 


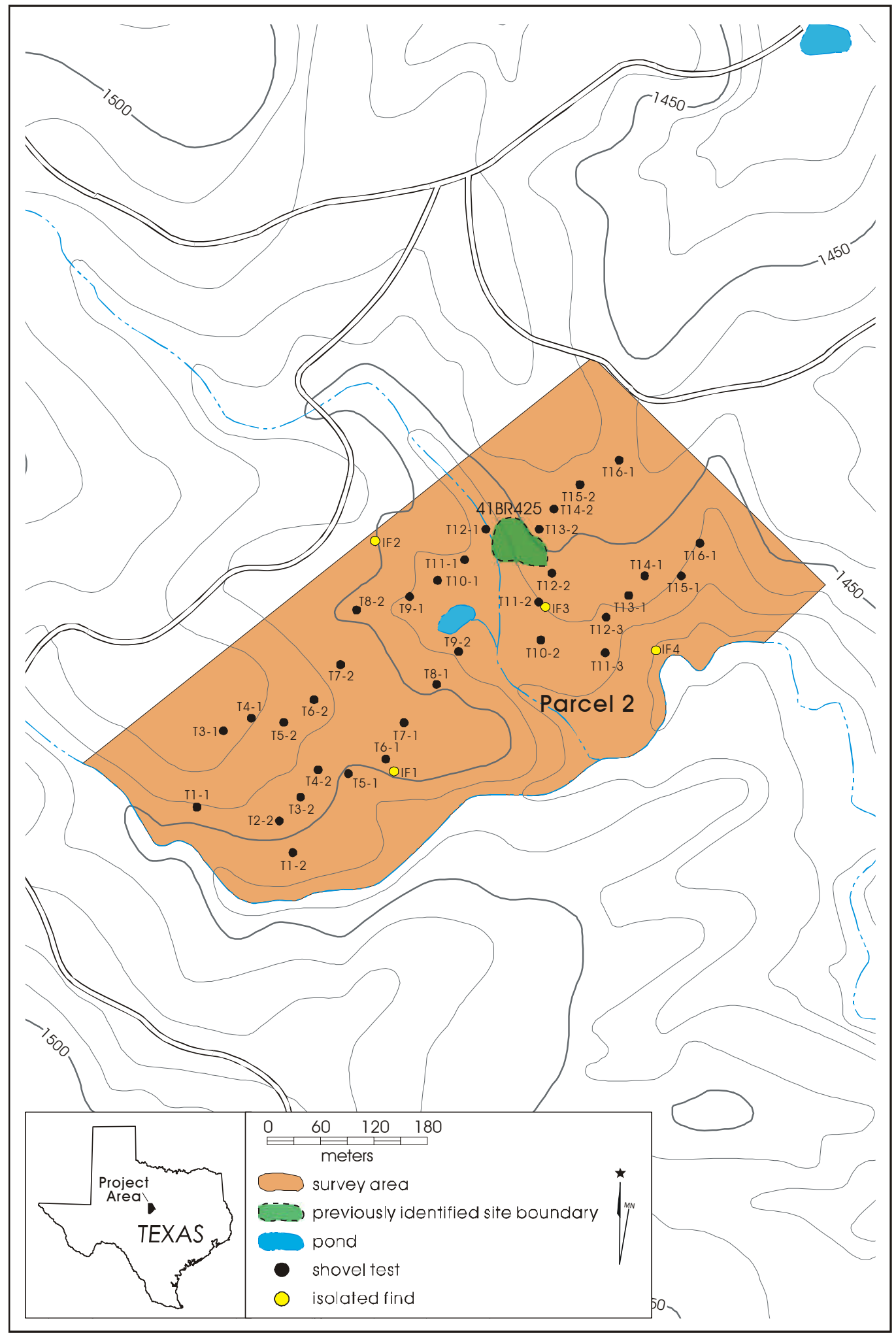

Figure 8. Locations of shovel tests in Parcel 2. 
2001:100) may be due to the identification of some of these naturally fractured cherts as primary flakes. Two efforts to relocate this site were made. An initial reconnaissance intensively examined the plotted location and identified the more probable area matching the previous site description. No surface artifacts were identified during this examination. During the survey and testing, a more intensive surface survey of this area with 10-m transect intervals between surveyors examined an area approximately $100 \mathrm{~m}$ northwestsoutheast by $100 \mathrm{~m}$ southwest-northeast. Most of this area had excellent surface visibility $(>60 \%)$. A single early stage biface (IF3) was recovered on the surface in this area. No surface flakes or other indications of an archaeological site were seen within the previously identified site area, the suspected location of the materials identified by Wormser and Sullo-Prewitt, or the vicinity of the isolated biface (IF3). Shovel tests in the vicinity of the suspected location of 41BR425 indicated no evidence of buried archaeological deposits. This site has probably been misevaluated through surface definition and is much more ephemeral than the previous description suggested.

No evidence of subsurface material was encountered in any of the shovel tests in Parcel 2. The four isolated finds also do not indicate the presence of any significant cultural resources within this parcel. Re-evaluation of the very ephemeral archaeological expression of 41BR425 does not indicate that this is a SAL or NRHP eligible resource. Normal military activities within this area should be allowed to proceed without further consultation with THC.

\section{Parcel 3}

Parcel 3 is an area of approximately 62 acres that was surveyed on November 14 and 16, 2001. A total of 43 shovel test units was excavated within this survey parcel (Figure 9). Several shovel tests were placed outside of the survey parcel because of the difficulty identifying the boundaries of this unit during fieldwork. Only one shovel test (T2-ST1) contained subsurface material (Table 3). Two pieces of heated angular debris were recovered from Levels 1 and 2 (0-20 cm bs) from this unit. Neither is unambiguously cultural in origin. No surface artifacts were identified. There are no cultural resources identified within this parcel that may be SAL or NRHP eligible. No additional archaeological investigations are considered necessary within this parcel. Normal military use of this area may proceed without further consultation with THC.

\section{Shovel Testing of 41BR248, 41BR467, 41BR469, and 41BR471}

Re-examination of four previously recorded sites was performed at the recommendation of Wormser and SulloPrewitt (2001:38-45). Three of these sites were successfully relocated during the shovel testing effort. The location and archaeological content of site 41BR248 could not be confirmed.

\section{BR248}

The mapped location of site 41BR248 was examined, but no evidence of surface artifacts was observed. Shovel testing produced no subsurface evidence of a site at this location. It is likely that this site location has been misplotted, or naturally fractured chert has been misidentified as cultural debris. The physical description and mapped location matched the area investigated, but no surface artifacts or subsurface prehistoric materials were encountered. The original description identified an area with 30-50 percent ground surface visibility (Wormser and Sullo-Prewitt 2001:60). The location matching the reported site position and the original site description exhibits excellent ground visibility ( $>40 \%)$. Adjacent areas are covered by dense grass and open oak forest. Two separate pedestrian examinations of the plotted site location and adjacent areas were performed, but no surface indications of any prehistoric

Table 3. Artifacts recovered from Parcel 3

\begin{tabular}{|c|c|c|l|l|}
\hline Shovel Test & $\begin{array}{c}\text { Maximum } \\
\text { Depth* }\end{array}$ & $\begin{array}{c}\text { Levels with Artifacts } \\
\text { Level \# (depth*) }\end{array}$ & \multicolumn{1}{|c|}{$\begin{array}{c}\text { Artifacts Collected } \\
\text { Kind (\#) }\end{array}$} & \multicolumn{1}{c|}{ Comments } \\
\hline T2-ST1 & $40 \mathrm{~cm}$ & $1(0-10 \mathrm{~cm})$ & angular debris $(1)$ & heat spall \\
\cline { 3 - 5 } & & $2(10-20 \mathrm{~cm})$ & angular debris (1) & heat spall \\
\hline
\end{tabular}

* centimeters below modern ground surface 


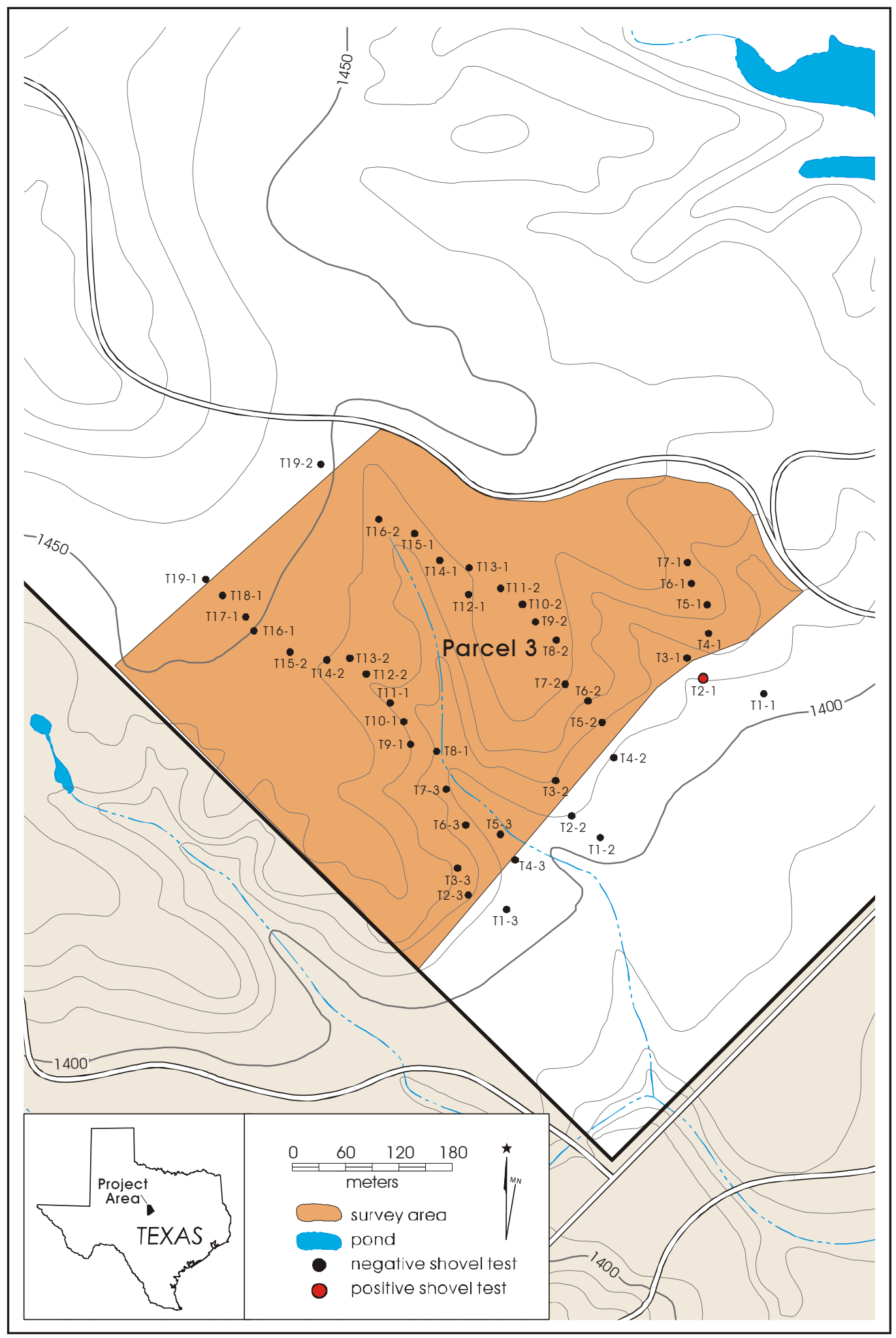

Figure 9. Locations of shovel tests in Parcel 3. 


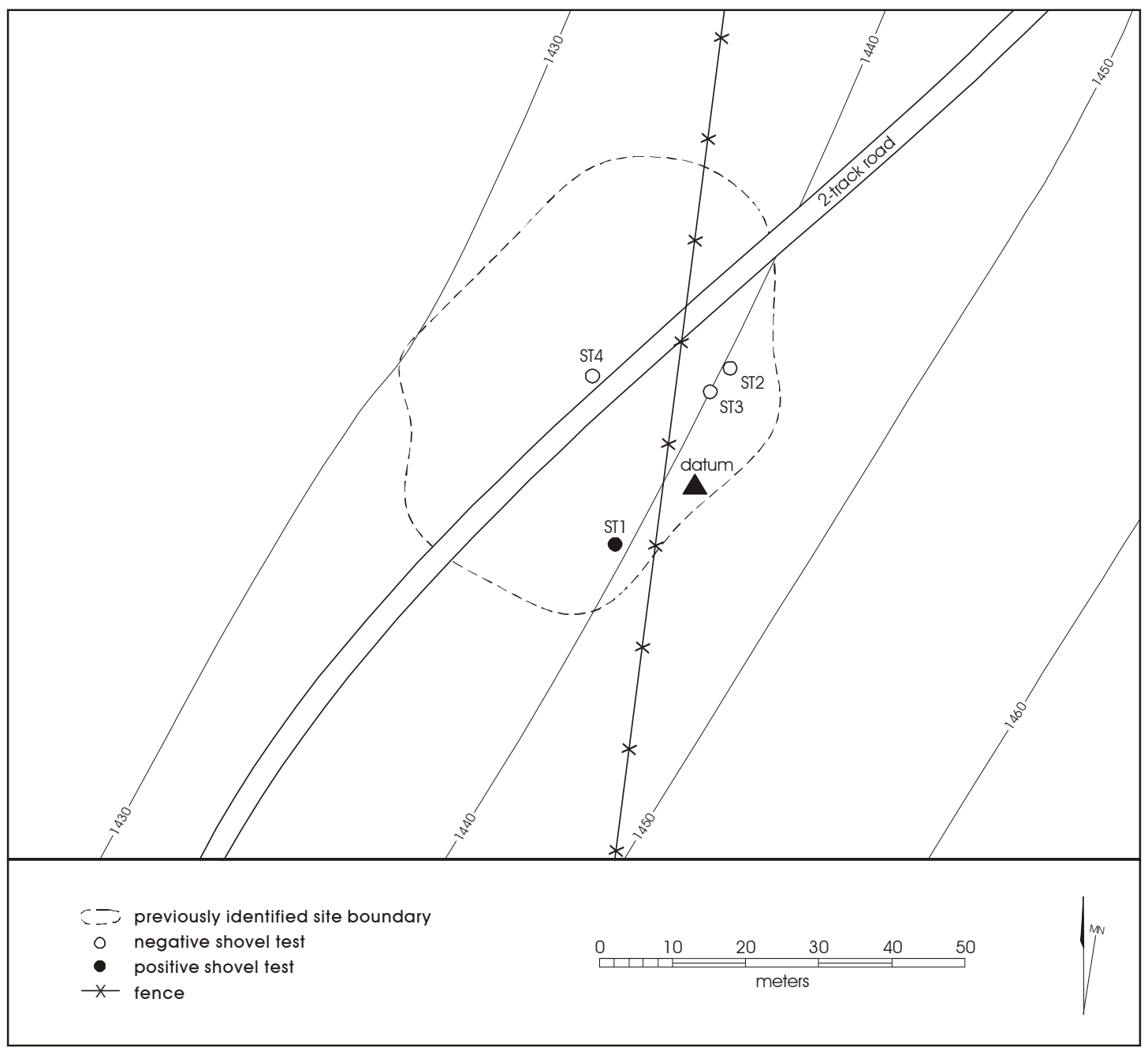

Figure 10. Site $41 B R 248$.

remains were encountered. A few naturally fractured chert gravels were seen, but no culturally produced lithics were evident. Four shovel tests were excavated at this location (Figure 10). Given the good-excellent surface visibility (>40\%) this effort was considered sufficient to determine if, indeed, an archaeological site meeting Texas survey standards exists at this location. Because 41BR248 was previously identified solely through a very ephemeral surface assemblage, three cores, two flakes, and one possible firecracked rock (Wormser and Sullo-Prewitt 2001:60), there is a strong possibility that there is no site at this location or in the vicinity. The naturally fractured cherts may have been misidentified as artifacts during the initial site characterization. Although the previously identified site boundaries are indicated in this figure, there is no apparent archaeological site at this location. No subsurface artifacts or suggestions of cultural features were encountered. A single mussel shell fragment and one piece of oxidized ferric metal were recovered from Level 4 of ST 1. Either natural chert fragments have been mistaken as artifacts, or this site is much more ephemeral than described, or the site location for 41BR248 has been misplotted. Several adjacent and likely areas were also examined during the two relocation efforts to determine whether an archaeological site as described in the initial recording by Wormser and SulloPrewitt (2001) could be identified nearby. Given the negative surface and subsurface results, project schedule and budget, additional relocation effort was unjustified. The THC recommendation that this site be tested may still need to be met by further investigation. It is recommended that a further 
attempt to relocate this site be performed so that testing of 41BR248 may be accomplished and its status as a definable archaeological site clarified.

\section{$41 \mathrm{BR} 467$}

Site 41BR467 is a low-density lithic scatter on a sloping upland ridge with moderate-to-heavy surface erosion. There is a sparse scatter of lithics present on the surface of this site with low-density concentrations associated only with good surface visibility in eroded areas (Figure 11). Bedrock is exposed on many parts of the surface and most soils are thin. Some areas clearly evidence colluvially redeposited sediments and artifacts. Wormser and Sullo-Prewitt (2001:118) indicate that this site had excellent surface visibility (70-100\%) during the initial survey and very sparse artifact presence. Human disturbance from construction and maintenance of a road has impacted the site. The site boundaries identified during this survey are significantly larger than the originally recorded dimensions of approximately $20 \times 20 \mathrm{~m}$ (Wormser and Sullo-Prewitt 2001:118). The current site dimensions are approximately $110 \mathrm{~m}$ northeast-southwest and maximally $53 \mathrm{~m}$ north-south. Surface artifacts were evident along a $100 \mathrm{~m}$-long portion of the existing road. The eastern end of the site extends slightly downslope and exhibits severe erosion. Bedrock was exposed at the surface over most of the western third of the site, in the north-central portion, and along the southeastern boundary areas. The currently inferred site boundaries were recorded with a GPS unit and four shovel tests were excavated on this site. Given that the ground surface visibility exceeded 30 percent and the goal of this effort was subsurface characterization, this represents a good sample of the subsurface material at this site. Bedrock was encountered between $8-19 \mathrm{~cm}$ in these units. Because of the excellent surface visibility, thin soils, and extensive bedrock exposure on this site, this was considered adequate testing of the subsurface archaeological material present in compliance with the survey standards for Texas. No artifacts were recovered in these shovel tests. Two cores and four bifaces were mapped and collected from the site surface (Figure 11, Table 4). Given the extensive evidence of erosion, colluvial transport of artifacts, and thin soils at this location, 41BR467 offers poor research potential to study human use of this area. No additional archaeological characterization of this site is considered necessary.

\section{BR469}

Site 41BR469 is a low density lithic scatter on very thin soil on a southward sloping upland ridge (Figure 12). Bedrock is exposed on several parts of the site. There is significant disturbance from the construction and maintenance of two roads across this site. The originally identified site boundaries were retained following examination of the site. The site is approximately $195 \mathrm{~m}$ north-south by 155 m east-west. Previous site examination identified a Dalton or Angostura-like point base (Wormser and Sullo-Prewitt 2001:119).

Six shovel tests were excavated in areas that appeared to have the deepest, most intact soils. Because the ground surface visibility exceeded 30 percent and the goal of this effort was subsurface characterization, and not necessarily redefinition of the site boundaries, these were considered a sufficient test in compliance with the survey standards for Texas. Bedrock was encountered between 6 and $42 \mathrm{~cm}$ bs. Several units encountered weathered bedrock zones indicating in situ soil development of an unknown age. Shovel tests ST 3, ST 4, and ST 6 were placed in areas of surface erosion (Figure 12). These locations did possess deeper soils (determined through probing) than other stabilized epipedons. Only one artifact was recovered subsurface; ST 5 contained a single flake from the first excavation level $(0-10 \mathrm{~cm} \mathrm{bs})$. The very low density of artifacts, relatively thin soils, evidence of surface erosion, and human impacts all suggest that 41BR469 has very limited research potential. No further archaeological investigation is considered necessary on this site.

\section{BR47 1}

Site 41BR471 is a moderate-to-high density lithic scatter that was re-examined during the current project. No dimensions of the site were reported previously (Wormser and Sullo-Prewitt 2001:120). Surface artifacts covered a maximum extent of approximately $95 \mathrm{~m}$ north-south by $35 \mathrm{~m}$ east-west (Figure 13). Surface visibility was excellent, Wormser and Sullo-Prewitt (2001:120) estimated that 75100 percent ground visibility characterizes this site. Although adjacent to an extensively modified stock tank, the identified area of the site does not appear to have been affected by that construction. One Late Prehistoric, side-notched projectile point was collected from the site surface. Two 


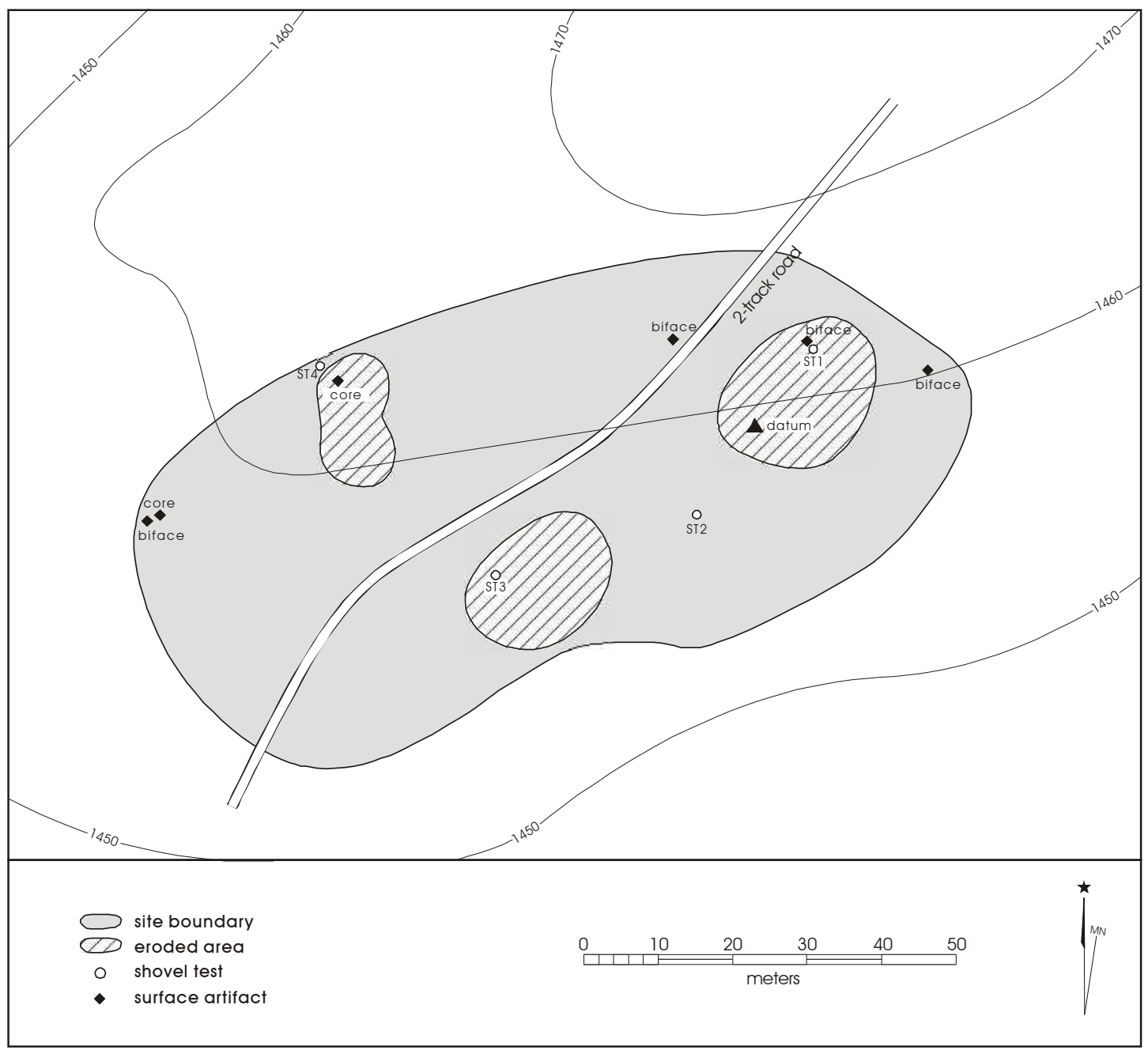

Figure 11. Site 41BR467.

Table 4. Artifacts recovered from 41BR467

\begin{tabular}{|c|c|l|l|}
\hline Shovel Test & $\begin{array}{c}\text { Levels with } \\
\text { Artifacts }\end{array}$ & \multicolumn{1}{|c|}{$\begin{array}{c}\text { Artifacts Collected } \\
\text { Kind (\#) }\end{array}$} & \multicolumn{1}{c|}{ Comments } \\
\hline surface & surface & biface fragment (1) & cortex present \\
\hline surface & surface & biface fragment (1) & late stage \\
\hline surface & surface & biface fragment (1) & cortex present \\
\hline surface & surface & multidirectional core (1) & poor quality raw material \\
\hline surface & surface & biface fragment (1) & \\
\hline surface & surface & multidirectional core (1) & much cortex \\
\hline
\end{tabular}




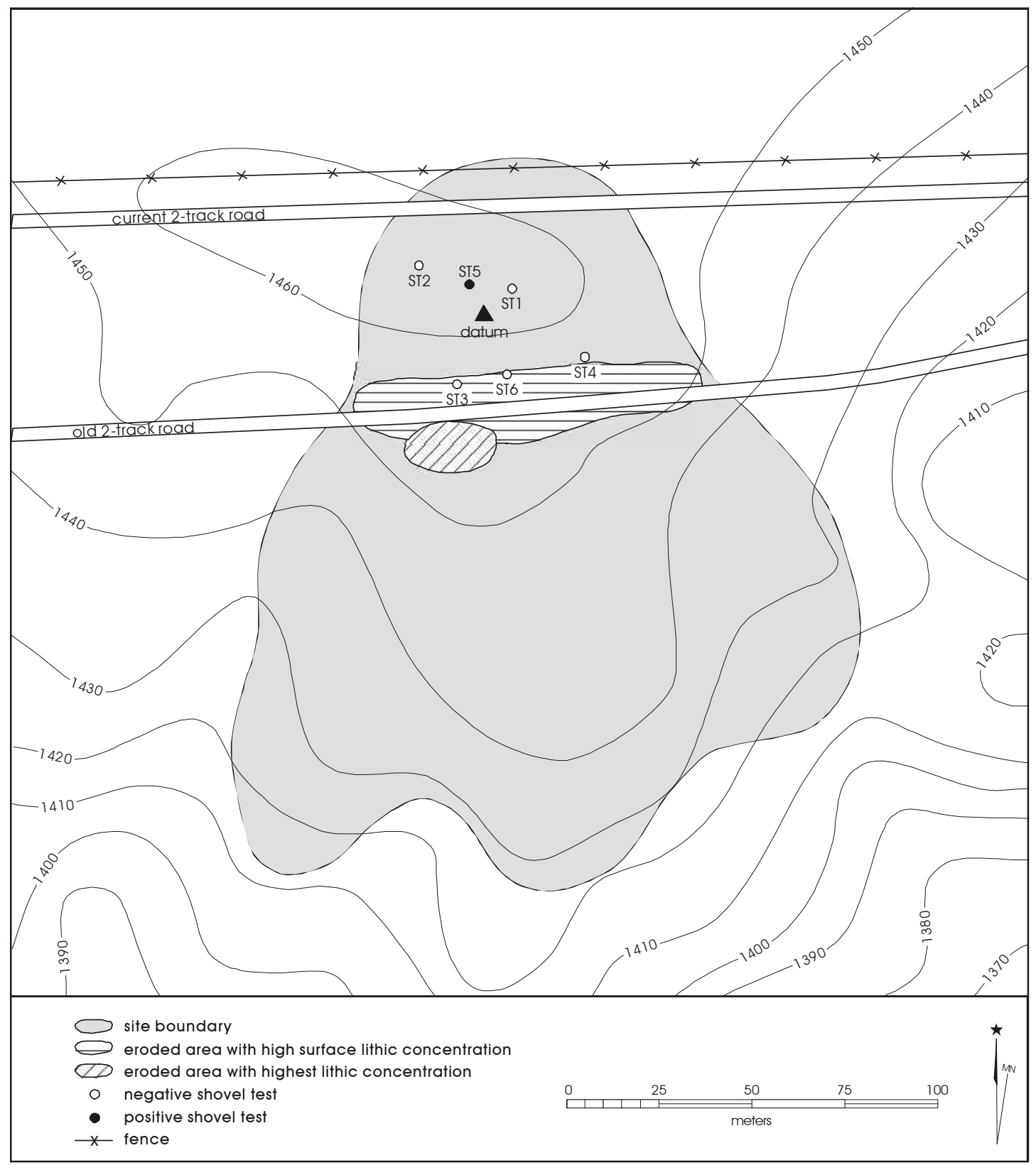

Figure 12. Site $41 B R 469$.

eroded portions of the site contained relatively dense scatters of lithics that included flakes and one core (collected). Four shovel tests were excavated on this site. Because the ground surface visibility exceeded 30 percent and the goal of this effort was subsurface characterization, and not necessarily redefinition of the site boundaries, these were considered an adequate test in compliance with the survey standards for Texas. Bedrock was encountered between $40-50 \mathrm{~cm}$ below the modern ground surface. A single piece of angular debris was recovered from within the first excavation level of one shovel test (ST 1; Table 5).

Although the site does not appear to contain subsurface archaeological deposits, this site may have some interesting 


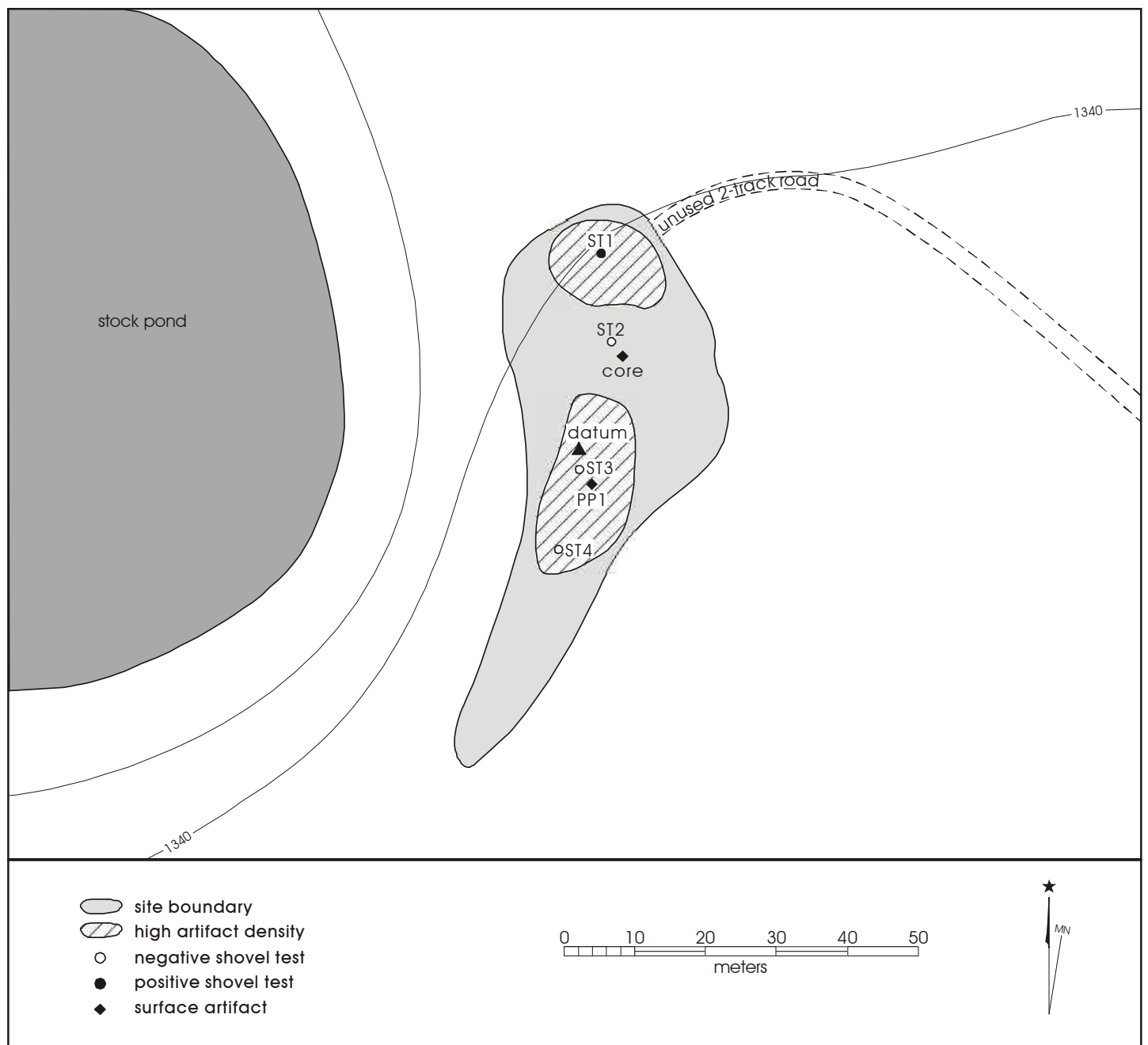

Figure 13. Site 41BR471.

Table 5. Artifacts recovered from 41BR471

\begin{tabular}{|c|c|c|l|l|}
\hline Shovel Test & $\begin{array}{c}\text { Maximum } \\
\text { Depth* }\end{array}$ & $\begin{array}{c}\text { Levels with Artifacts } \\
\text { Level \# (depth*) }\end{array}$ & \multicolumn{1}{|c|}{$\begin{array}{c}\text { Artifacts Collected } \\
\text { Kind (\#) }\end{array}$} & Comments \\
\hline ST 1 & $50 \mathrm{~cm}$ & $1(0-10 \mathrm{~cm})$ & angular debris (1) & \\
\hline surface & 0 & surface & projectile point (1) & Late Prehistoric \\
\hline surface & 0 & surface & multidirectional core (1) & \\
\hline surface & 0 & surface & flakes (4) & all complete \\
\hline
\end{tabular}

* centimeters below modern ground surface 
research potential. There is a relatively high density of surface flakes and surface collection could produce a useful representative lithic sample. This site may offer an opportunity to study a small, perhaps short-term use site within this area. There is a strong possibility, suggested by the small size and density of materials, that this may be a single or limited occupation site. Although much material is exposed through deflation, there may be some horizontal spatial integrity to this site. The surface-collected point is a small, side-notched Late Prehistoric point missing its distal tip and has damage to both basal ears. There is basal thinning and perhaps basal notching of this piece. It resembles Harrell or Toyah points (Turner and Hester 1993:217, 234). This site's research potential for examination of limited occupation surface sites should be compared with other small sites identified within Camp Bowie. The need for further examination can be determined through comparison with the research potential of these other small sites. There is a strong likelihood that $41 \mathrm{BR} 471$ could provide a useful sample of lithics, spatial patterning data, and information about variability in low density site context for comparison with other small and large archaeological sites in this area. It is recommended that additional testing be carried out at this site. Based on the current testing, the potential SAL and NRHP eligibility of 41BR471 is unknown. This site should be protected and avoided if possible. If protection at this location cannot be effected, then additional testing is necessary to determine the integrity and potential significance of 41BR471.

\section{Previous Investigations of 41BR392 and 41BR523}

Site 41BR392 was originally reported by Wormser and SulloPrewitt (2001:87). During an early visit to this site by CAR and TXANG archaeologists, the possible presence of a burned rock midden was noted. Such a feature was not recorded in the original documentation of this site. Consequently, in February 2001, CAR revisited 41BR392 and conducted work on this site in order to document the midden.

41BR523 was originally identified by the TXANG survey of Camp Bowie. However, while the location of the site was noted on survey maps, no additional information on the site could be located. Consequently, CAR archaeologists revisited the location and collected information regarding the nature of the site.
The locations of 41BR392 and 41BR523 within Camp Bowie are shown in the Map Supplement.

\section{BR392}

This site was previously recorded as a historic site (Wormser and Sullo-Prewitt 2001:87). The location of a historic chimney in the southeastern portion of the site and a historic period stone wall in the northwestern part of the site were mapped with a GPS unit during the re-examination of the site in February of 2001 (Figure 14). Surface visibility during this investigation was approximately 40 percent, exceeding that estimated during the initial description (Wormser and Sullo-Prewitt 2001:87). A burned rock midden was identified at the southwestern end of the stone wall. Two shovel tests were excavated to evaluate the midden and adjacent area. Given the surface visibility and extent of historic disturbances, this was considered an adequate initial test, without controlled $1 \times 1-\mathrm{m}$ excavation units, of the subsurface potential of this prehistoric component. Under the conditions of 40 percent surface visibility, these two shovel tests are in compliance with the survey standards for the state of Texas. One of the shovel tests (ST 1) was placed in the center of the midden and excavated to a depth of 25 $\mathrm{cm}$. Abundant fire-cracked sandstone was encountered in this unit in addition to dark, charcoal-stained soil. The other shovel test was placed on the eastern side of the midden away from the rock concentration. A recent shotgun shell metal casing was recovered from Level $2(10-20 \mathrm{~cm} \mathrm{bs})$ and a flake from Level 5 ( $40-50 \mathrm{~cm}$ bs) of ST 2 (Table 6). The uppermost $40 \mathrm{~cm}$ of this unit exhibited recent disturbance. Below $40 \mathrm{~cm}$, the soil appears to be intact. A complete Bulverde projectile point was collected from the site surface (Figure 15). Although considered indicative of Middle Archaic time periods (Turner and Hester 1993), its presence on the surface of a site with a historic occupation may not indicate association with the prehistoric component. The temporal affiliation of the midden must currently be considered ambiguous because this point could have been collected by the occupants of the historic household. The feature on this site is one of only two burned rock middens at Camp Bowie that have not received additional testing. Given the uncertainty about its potential date and the presence of abundant charcoal-stained soil that suggests good preservation conditions, additional testing of this site is recommended. The potential SAL and NRHP eligibility of 41BR392 is currently unknown. This site should be 


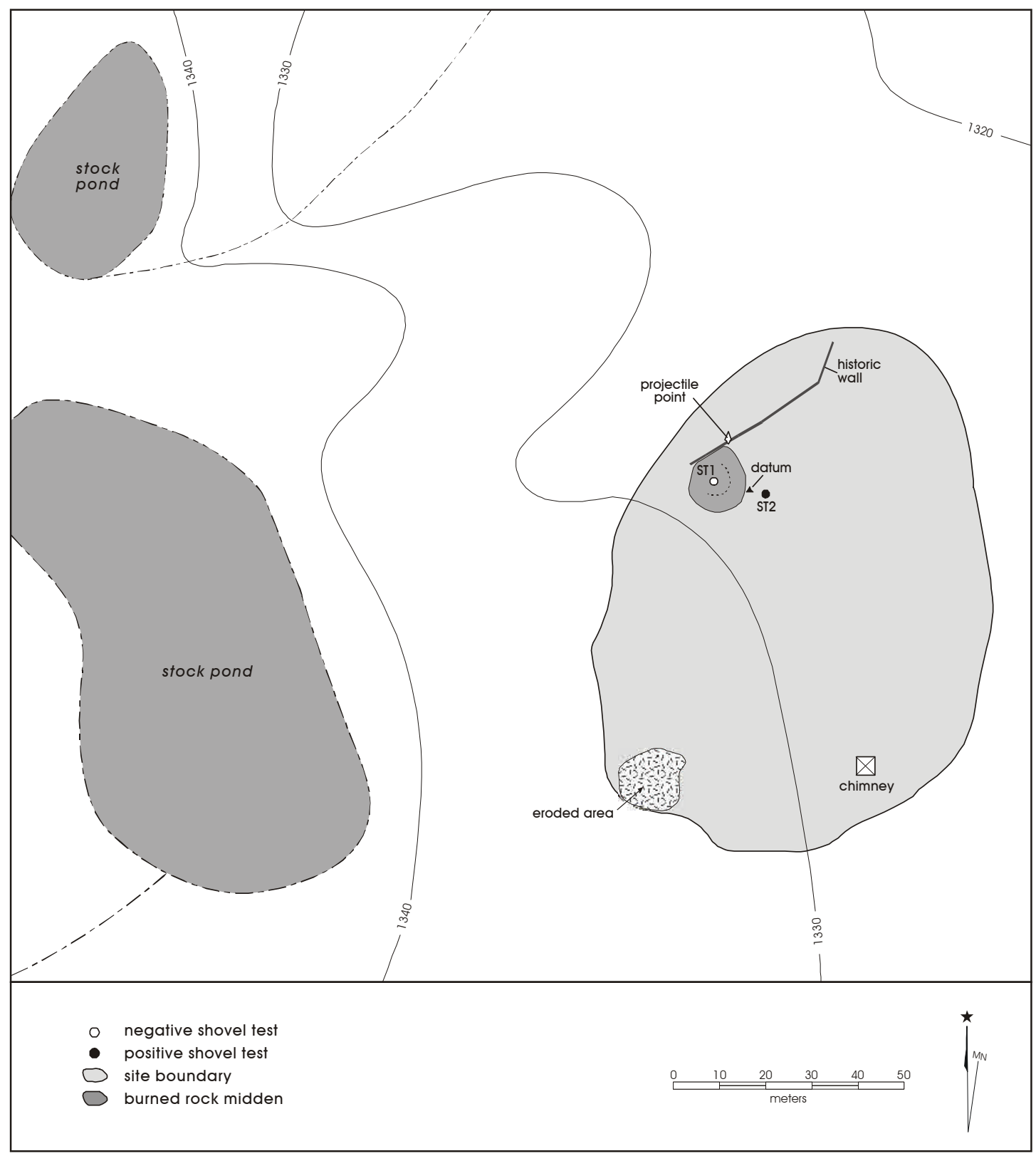

Figure 14. Site 41BR392.

Table 6. Artifacts recovered from 41BR392

\begin{tabular}{|c|c|c|l|l|}
\hline Shovel Test & $\begin{array}{c}\text { Maximum } \\
\text { Depth* }\end{array}$ & $\begin{array}{c}\text { Levels with Artifacts } \\
\text { Level \# (depth*) }\end{array}$ & \multicolumn{1}{|c|}{$\begin{array}{c}\text { Artifacts Collected } \\
\text { Kind (\#) }\end{array}$} & \multicolumn{1}{c|}{ Comments } \\
\hline surface & 0 & surface & projectile point (1) & Bulverde (Middle Archaic) \\
\hline ST 2 & 50 & $2(10-20 \mathrm{~cm})$ & shotgun shell casing (1) & Winchester \\
\cline { 2 - 5 } & & $5(40-50 \mathrm{~cm})$ & flake $(1)$ & distal fragment \\
\hline
\end{tabular}

* centimeters below modern ground surface 


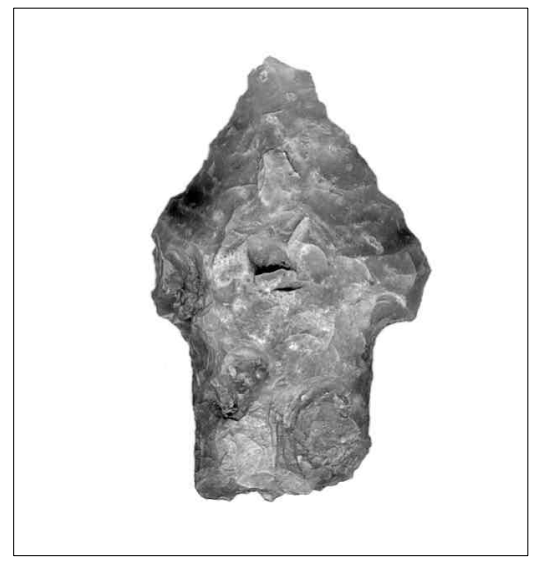

Figure 15. Bulverde point recovered from site $41 B R 392$.

protected and avoided if possible. If the site cannot be protected, then additional testing is necessary to determine the integrity and potential significance of 41BR392.

\section{$41 \mathrm{BR} 523$}

Site 41BR523 is a military field training facility including a live grenade court that appears to date to the period of World War II. No specific information is available about this location. No comparable range facility or grenade court has been previously described for Camp Bowie (Wormser and Sullo-Prewitt 2001:Table 2). Camp Bowie was the largest military training camp in Texas preparing soldiers for WW II (Leffler 2002:19); several such range facilities are likely present within the camp. The location of 41BR523 is noted on survey maps, but no additional documentation on the site could be found and there is no permanent architecture associated with the site. Information from contemporary maps of Camp Swift, a WW II-era Army training facility in Bastrop County, Texas, indicates that firing and combat ranges were located in specified zones and their impact fans were directed toward the facility interior (Robinson et al. 2001:172). Similar range facility segregation and the destructive impacts on prehistoric archaeological sites are documented at Camp Maxey, Lamar County, Texas (Mahoney 2001a:53, 2001b:Figure 12). Site 41BR523 is not located adjacent to other military facility remains and the grenade court's impact fan faces the interior of Camp Bowie.

41BR523 consists of a bermed area associated with a trench that is a grenade court in the southeastern quadrant of the site, a scatter of historic military debris, and a small bermed area at the northern end of the site (Figure 16). The function of this northern area is unknown. The live grenade court is the most robust portion of this site (Figures 17 and 18). The easternmost portion of the grenade court is an area containing scrap metal fragments, presumably representing practice grenades. An unexploded WW II-era grenade was identified in this area (Figure 19). At the western margin of this area is a berm facility with ten bays facing to the west. This berm is approximately $88 \mathrm{~m}$ north-south and has been built up 3 $\mathrm{m}$ high. Approximately $10-15 \mathrm{~m}$ to the west of the eastern face of this berm is a 2-m deep trench that is partially infilled. Just west of the trench is an accumulation of hand grenade tops (Figure 20). No testing was performed at this range facility. This site is not considered to be eligible as a SAL or NRHP property. No additional characterization is considered necessary at 41BR523. 


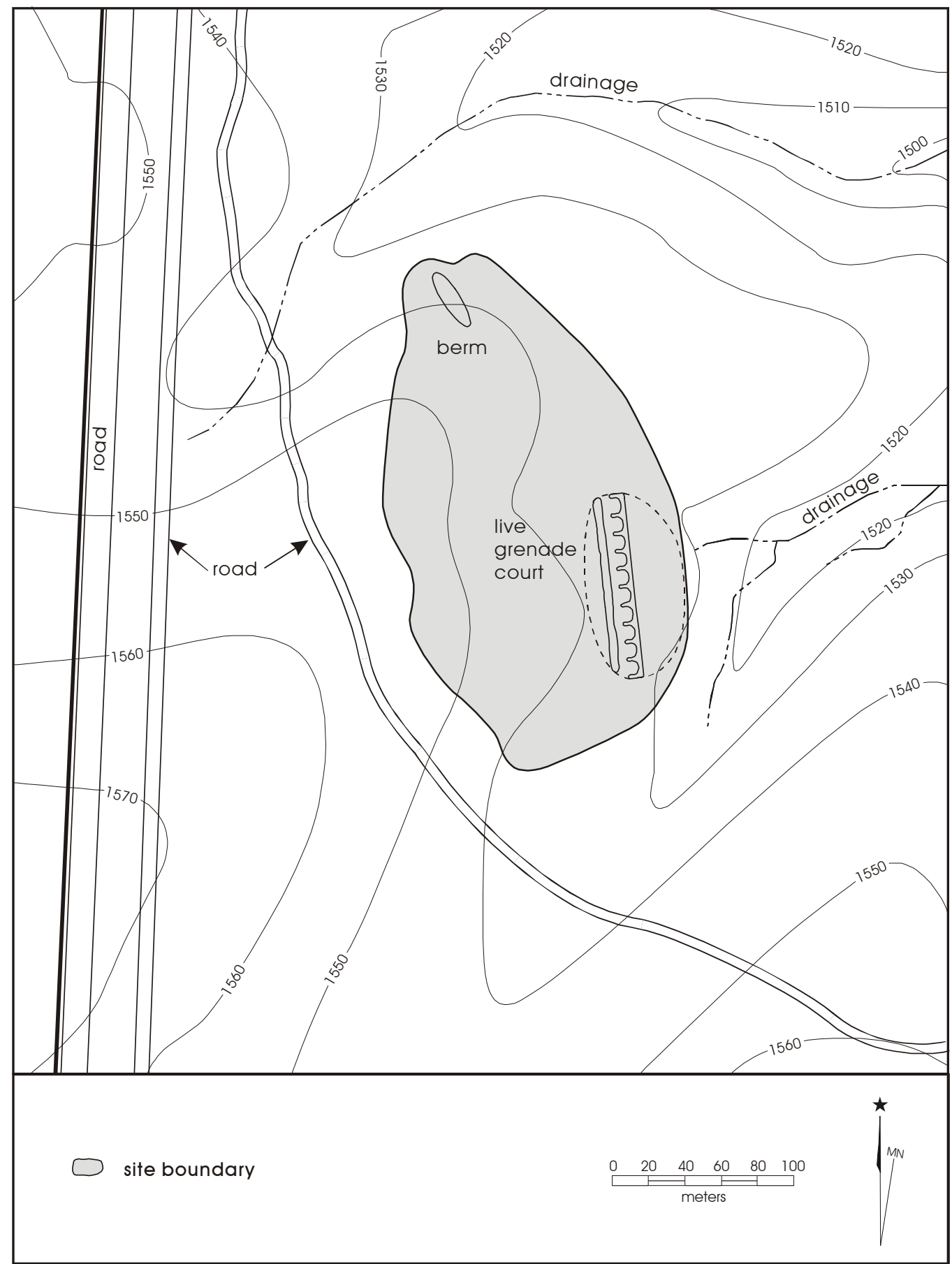

Figure 16. Site 41BR523, World War II-era range facility with grenade court. 


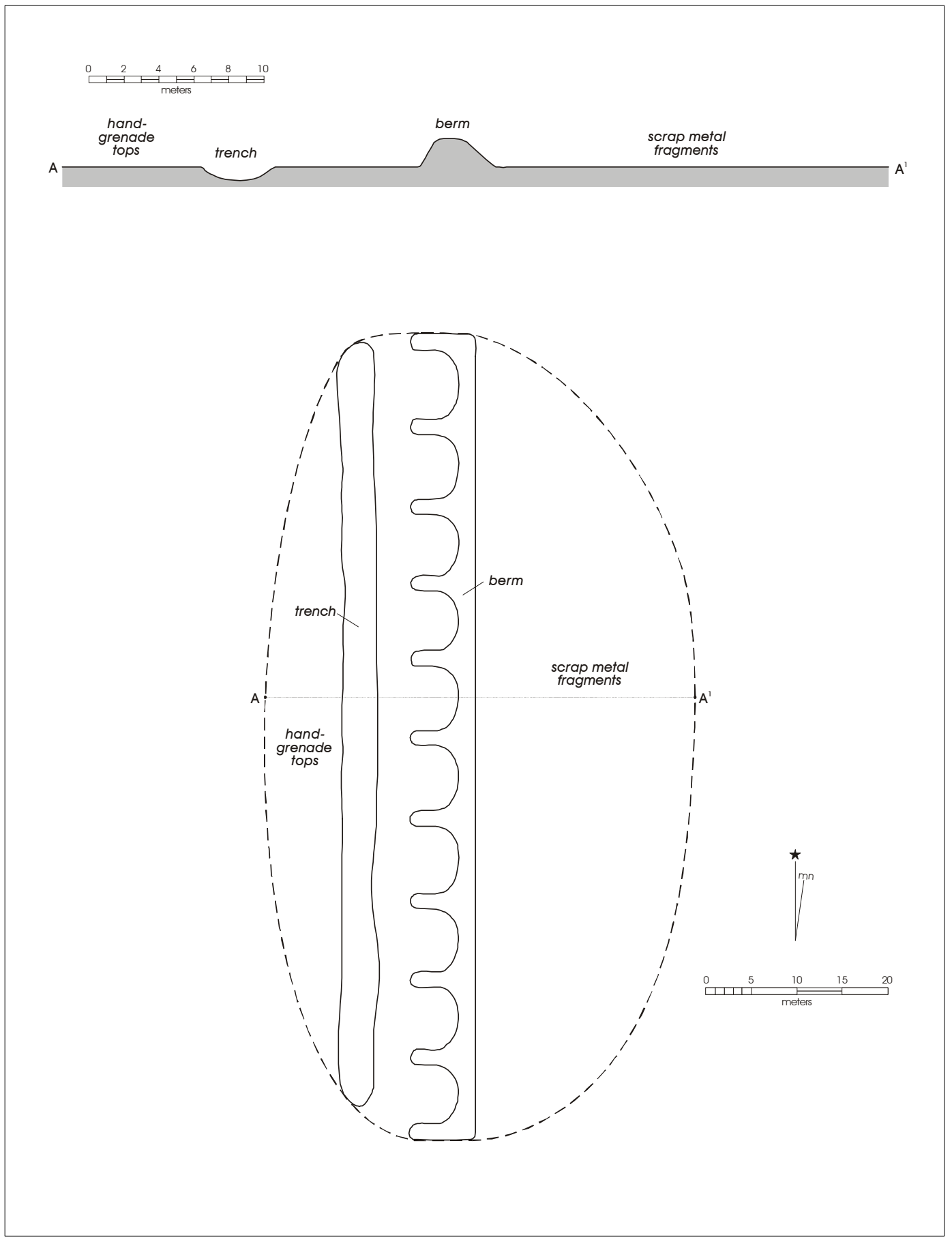

Figure 17. Grenade court, 41BR523. 


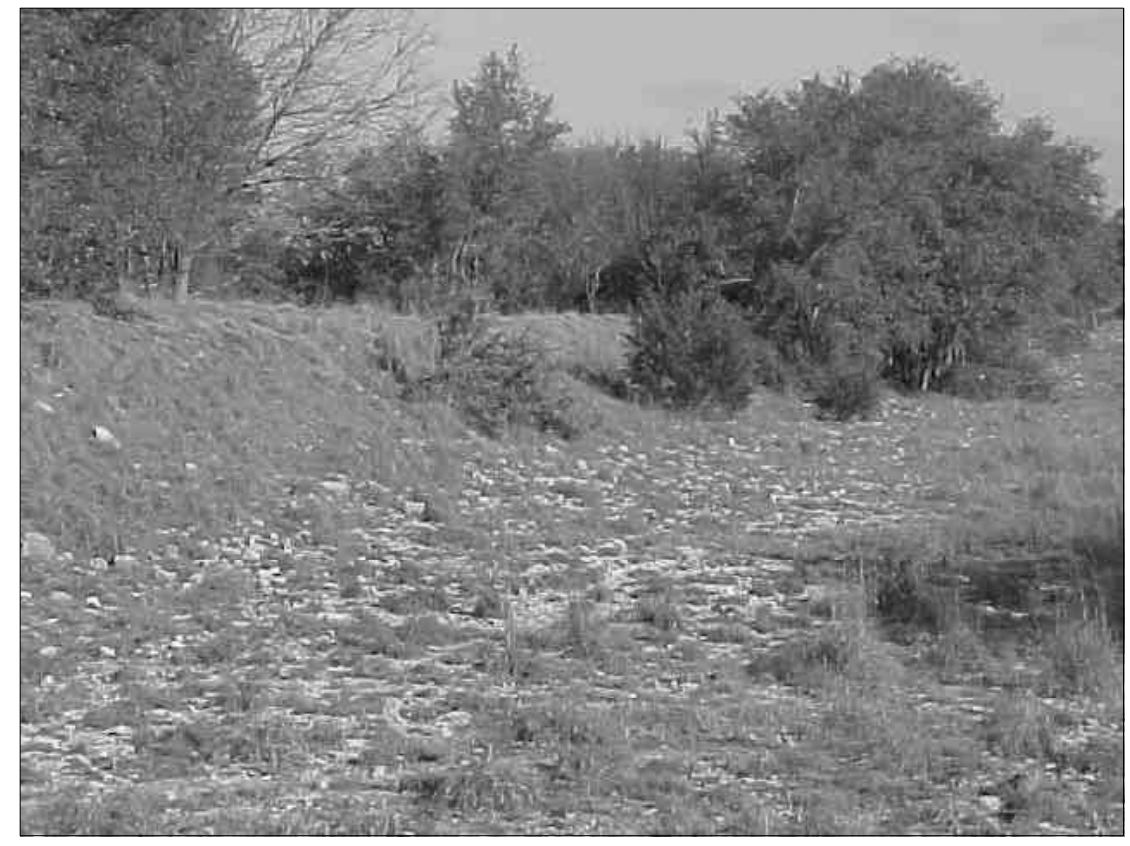

Figure 18. Berm in the grenade court of 41BR523, looking northwest.

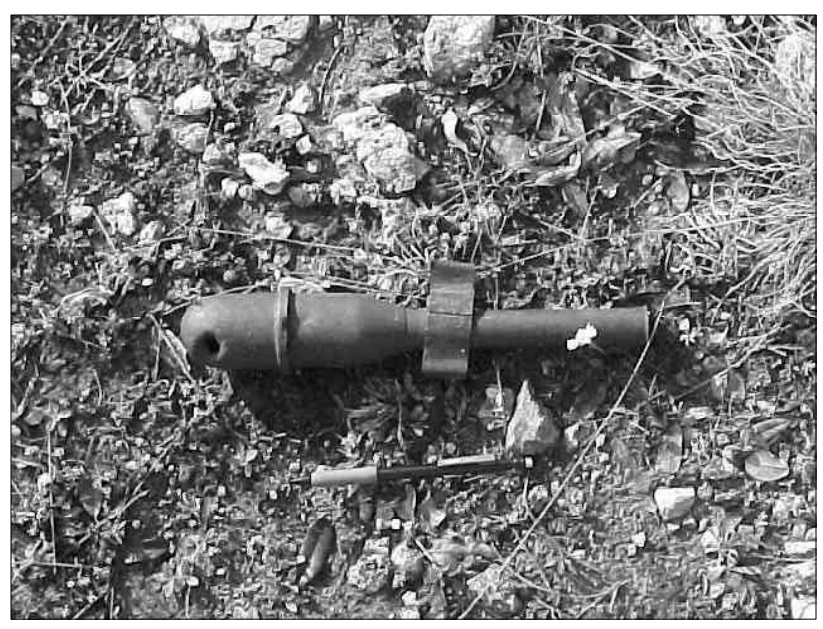

Figure 19. Unexploded World War II-era grenade observed on site $41 B R 523$.

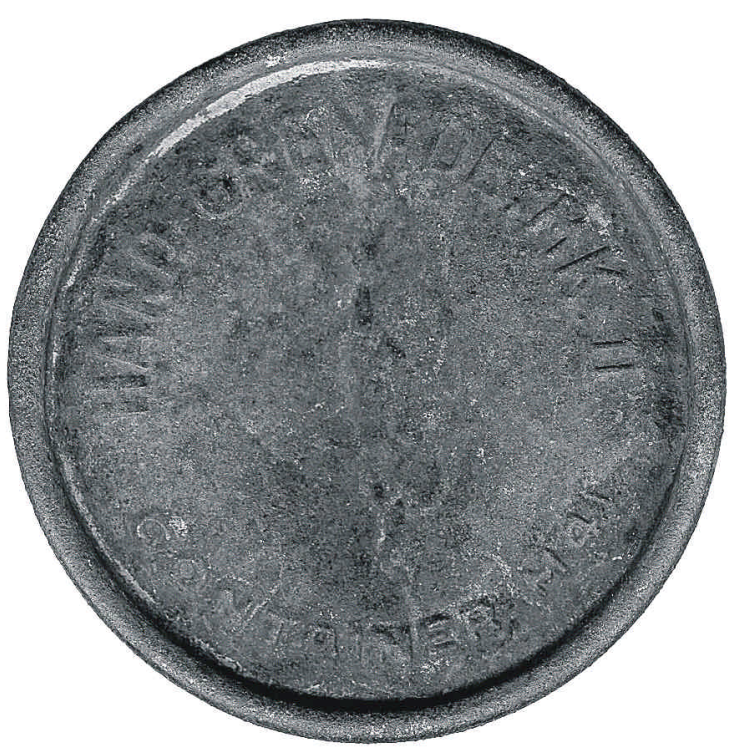

Figure 20. Grenade can lid found on 41 BR523. 



\section{Chapter 6: Project Summary and Recommendations}

Based on the archaeological survey inventory conducted by CAR, it was determined that protection or additional archaeological work be recommended at sites 41BR522 and 41BR471. The survey also determined that no areas of Parcels 1, 2, and 3 contained significant archaeological remains that could be identified during the course of this effort as the shovel testing methods employed did not evaluate sediments deeper than $60 \mathrm{~cm}$ below the modern ground surface. Although, it should also be noted that the Nukrum soils of Parcel 1 do have "high potential" to contain buried archaeological deposits. Therefore, it is recommended that any planned deep excavation efforts within the alluvial soils of Parcel 1 involve archaeological monitoring of those deposits. Normal military use of these parcels will not affect any identified cultural resources (with the noted exception of 41BR522). Use of these areas may proceed with no further consultation with THC.

Re-evaluation of four previously recorded sites, 41BR248, 41BR467, 41BR469, and 41BR471, indicate that just the latter appears to have "high probability" to contain significant research potential. Protection and avoidance of 41BR471 is recommended and additional testing is highly desirable to clarify its SAL and NRHP eligibility. No additional work is considered necessary at 41BR467 and 41BR469. These sites are ineligible for nomination as SAL or NRHP properties. No further consultation with THC is necessary for 41BR467 and 41BR469. Site 41BR248 could not be relocated; either it is not an archaeological site, is more ephemeral than previously indicated, or its previously plotted location is incorrect. Additional effort would be required to further attempt to evaluate whether there is a site matching the initial description, or to relocate 41BR248 in the vicinity of the misplotted location, and then perform testing to determine its potential SAL and NRHP eligibility.

Additional testing is recommended on site 41BR392 previously recorded in February of 2001, while no further work is considered necessary to document 41BR523, the military training facility area.

Specific recommendations for sites 41BR522, 41BR471, 41BR392, and 41BR248 are provided in the following.

\section{BR522}

Additional testing of this site is strongly recommended. The burned rock midden appears to be intact and the adjacent sediments are relatively undisturbed and have a strong potential for buried archaeological material. The apparent association of only a small area containing archaeological material and its position away from any larger, identified site, offers a unique control opportunity at Camp Bowie. 41BR522 provides an excellent case-study to examine the patterning and material associations of a single-use episode unassociated with palimpsest deposits from multiple activities. Due to these characteristics, intensive testing of this site is recommended.

The placement of a $1 \times 3-\mathrm{m}$ excavation unit crossing the center of this feature and extending to the east would provide a significant sample and profile of this midden. A single $1 \times 1-\mathrm{m}$ or $1 \times 2$-m unit at the eastern margin would provide a critical profile to examine the relationship of the feature margin to a prehistoric soil surface. Additional shovel testing established on a grid, sampled at 5-m intervals, would aid in determining the spatial distribution of artifacts in relation to the burned rock midden feature. Based on results of this survey and testing of 41BR522, and contingent on the results of additional testing, judgment placement of two to three $1 \times 1-m$ units is critical to determine the significance and research value of this site. A significant sample of the surrounding sediments can provide a very fine-scale view of this potentially single-component feature. If feasible, some of these units should be contiguous to take advantage of the potential for useful spatial analyses.

\section{BR471}

This is an extensive site with significant amounts of surface material. There does not appear to be a strong probability that subsurface deposits are deep or well-preserved, however, the relatively dense amount of surface material may provide a significant opportunity to obtain a comprehensive sample of artifacts from a small site. The utility of this sample in comparison with other sites within Camp Bowie could be extremely valuable. There is a strong possibility that this site represents a short-term, perhaps single occupation event. Additional testing employing a 
minimum of three to five $1 \times 1-\mathrm{m}$ units is recommended. These may help address whether a subsurface component is present on the site and its relationship to the surface materials. In addition, an intensive 100 percent surface collection of a minimum of ten $1 \times 1-\mathrm{m}$ collection areas is recommended. A large assemblage obtained through controlled surface collection may aid in understanding the dynamics of site reuse in this area. This additional characterization is considered necessary to determine the SAL and NRHP eligibility of this site.

\section{BR392}

The burned rock midden at this site contains abundant dark stained sediment and may produce charcoal suitable for dating. This is one of only two burned rock middens on Camp Bowie that have not been tested beyond initial shovel test examination. A minimum of three controlled $1 \times 1-\mathrm{m}$ units should be placed within the midden. Additional shovel testing established on a grid, sampled at 5-m intervals, would help determine the spatial distribution of artifacts in relation to the burned rock midden feature. Based on shovel test results, an additional two to three $1 \times 1$-m units should be placed around this feature to determine whether prehistoric materials are associated with it.

\section{$41 \mathrm{BR} 248$}

No evidence of an archaeological site was identified during two examinations of the previously recorded location of this site. The physical description and mapped location matched the area investigated, but no surface artifacts or subsurface prehistoric materials were encountered. This site could not be found at or near the vicinity of its plotted location. It is possible that there may be no archaeological site at this location. An additional testing effort may be necessary to find and test this site to determine its potential SAL and NRHP eligibility. 


\section{References Cited}

Adjutant General's Department of Texas

1992 Environmental Assessment, Camp Bowie Land Acquisition. Manuscript on file, Adjutant General's Department of Texas, Facilities and Engineering, Austin, Texas.

Black, S. L.

1986 The Clemente and Herminia Hinojosa Site, 41JW8: A Toyah Horizon Campsite in Southern Texas. Special Report No. 18. Center for Archaeological Research, The University of Texas at San Antonio.

1989a Central Texas Plateau Prairie. In From the Gulf Coast to the Rio Grande: Human Adaptation in Central, South and Lower Pecos Texas, by T. R. Hester, S. L. Black, D. G. Steele, B. W. Olive, A. A. Fox, K. J. Reinhard, and L. C. Bement, pp. 17-38. Research Series No. 33. Arkansas Archeological Survey, Fayetteville.

1989b South Texas Plain. In From the Gulf Coast to the Rio Grande: Human Adaptation in the Central, South, and Lower Pecos Texas, by T. R. Hester, S. L. Black, D. G. Steele, B. W. Olive, A. A. Fox, K. J. Reinhard, and L. C. Bement, pp. 39-62. Research Series No. 33. Arkansas Archeological Survey, Fayetteville.

Black, S. L., and A. J. McGraw

1985 The Panther Springs Creek Site: Cultural Change and Continuity in the Upper Salado Creek Drainage, SouthCentral Texas. Archaeological Survey Report, No. 100. Center for Archaeological Research, The University of Texas at San Antonio.

Black, S. L., L. W. Ellis, D. G. Creel, and G. T. Goode

1997 Hot Rock Cooking on the Greater Edwards Plateau: Four Burned Rock Midden Sites in West Central Texas. 2 vols. Studies in Archeology 22, Texas Archeological Research Laboratory, The University of Texas at Austin; Archeology Studies Program, Report 2, Environmental Affairs Department, Texas Department of Transportation, Austin.

Bousman, C. B.

1998 Paleoenvironmental Change in Central Texas: The Palynological Evidence. Plains Anthropologist (43)164:201219.

Briggs, A. K.

1992 An Archaeological Survey of Sample Areas within the Proposed Camp Bowie Acquisition Area, near Brownwood, Brown County, Texas. Manuscript on file, Texas Historical Commission, Austin, Texas.

Campbell, T. N.

1952 Early Archaeological Investigations in the Vicinity of Brownwood, Texas. The Record 10(3):10-14.

Campbell, T. N., and T. J. Campbell

1981 Historic Indians of the Choke Canyon Reservoir Surrounding Area, Southern Texas. Choke Canyon Series, No. 1. Center for Archaeological Research, The University of Texas at San Antonio.

Clower, D. F.

1980 Soil Survey of Brown and Mills County, Texas. United States Department of Agriculture, Soil Conservation Service and the Texas Agricultural Experimental Station.

Collins, M. B.

1995 Forty Years of Archeology in Central Texas. Bulletin of the Texas Archeological Society 66:361-400. 
Collins, M. B., W. A. Gose, and S. Shaw

1994 Preliminary Geomorphological Findings at Dust and Nearby Caves. Journal of Alabama Archaeology 40:3556.

Creel, D. G.

1986 A Study of Prehistoric Burned Rock Middens in West Central Texas. Unpublished Ph.D. dissertation, The University of Arizona, Tucson.

Dillehay, T.

1974 Late Quaternary Bison Population Changes on the Southern Plains. Plains Anthropologist 19(64):180-196.

Fenneman, N.

1931 Physiography of the Western United States. McGraw Hill, New York.

Fox, A. A., and D. E. Fox

1967 The Classen Rockshelter, 41BX23. Manuscript on file, Center for Archaeological Research, The University of Texas at San Antonio.

Gearhart, B., and M. W. Voellinger

1986 Archaeological Testing on Sites 41BR313 and 41BR314, Brown County, Texas. Manuscript on file, Texas Historical Commission, Austin, Texas.

Givens, R. D.

1968 A Preliminary Report on Excavations at Hitzfelder Cave. Bulletin of the Texas Archeological Society 38:47-50.

Goode, G. T.

1991 Late Prehistoric Burned Rock Middens in Central Texas. In The Burned Rock Middens of Texas: An Archaeological Symposium, edited by T. R. Hester, pp. 71-93. Studies in Archeology 13. Texas Archeological Research Laboratory, The University of Texas at Austin.

Gould, F. W.

1975 Texas Plants—A Checklist and Ecological Summary. Bulletin MP-585:5-14. Texas Agricultural Experimentation Station, College Station.

Hall, G. D.

1981 Allens Creek: A Study in the Cultural Prehistory of the Brazos River Valley, Texas. Research Report 61. Texas Archeological Survey, The University of Texas at Austin.

Hester, T. R.

1991 The Burned Rock Middens of Texas: An Archeological Symposium. Studies in Archeology 13. Texas Archeological Research Laboratory, The University of Texas at Austin.

1995 The Prehistory of South Texas. Bulletin of the Texas Archeological Society 66:427-459.

Highley, L., C. Graves, and G. Judson

1978 Archeological Investigations at Scorpion Cave (41ME7), Medina County, Texas. Bulletin of the Texas Archeological Society 49:139-194. 
Hofman, J. L.

1989 Prehistoric Culture History-Hunters and Gatherers in the Southern Great Plains. In From Clovis to Comanchero: Archeological Overview of the Southern Great Plains, by J. L. Hofman, R. L. Brooks, J. S. Hays, D. W. Owsley, R. L. Jantz, M. K. Marks, and M. H. Manhein, pp. 25-60. Research Series No. 35. Arkansas Archeological Survey, Fayetteville.

Houk, B. A., and J. C. Lohse

1993 Archeological Investigations at the Mingo Site, Bandera County, Texas. Bulletin of the Texas Archeological Society 61:193-247.

Howard, M. A.

1991 Burned Rock Midden Excavations, Hearths and Botanical Remains. In The Burned Rock Middens of Texas: An Archeological Symposium, edited by T. R. Hester, pp. 45-69. Studies in Archeology 13. Texas Archeological Research Laboratory, The University of Texas at Austin.

Huebner, J. A.

1991 Late Prehistoric Bison Populations in Central and Southern Texas. Plains Anthropologist 36(137):343-358.

Hurt, R. D.

1980 Archeological Investigations of Portions of the Middle Concho Valley. Unpublished Master's Thesis, Texas Tech University, Lubbock.

Johnson, E., and V. T. Holliday

1986 The Archaic Record at Lubbock Lake. In Current Trends in Southern Plains Archeology, edited by T. G. Baugh. Plains Anthropologist Memoir 22:7-54.

Johnson, L., Jr.

1995 Past Cultures and Climates at Jonas Terrace, 41ME29, Medina County, Texas. Office of the State Archeologist, Report 40. Texas Department of Transportation and Texas Historical Commission, Austin.

Johnson, L., and G. T. Goode

1994 A New Try at Dating and Characterizing Holocene Climates, as well as Archaeological Periods, on the Eastern Edwards Plateau. Bulletin of the Texas Archeological Society 65:1-51.

Kegley, G. P., and A. Black

1978 An Archaeological Survey of Cordell and Camp Bowie City Park Sites, Brownwood, Texas. Texas Antiquities Committee, Austin, Texas.

Kirby, F. E., and R. Moir

1976 Brownwood Dam Modifications and Archaeological Assessment. Reports in Archaeology No. 95. Archaeology Research Program, Southern Methodist University, Dallas, Texas.

Leach, J. D., and C. B. Bousman

2001[1998] Cultural and Secondary Formation Processes: On the Dynamic Accumulation of Burned Rock Middens. In Test Excavations at the Culebra Creek Site, 41BX126, Bexar County, Texas, by D. L. Nickels, C. B. Bousman, J. D. Leach, and D. A. Cargill, pp. 119-145. Archaeological Survey Report, No. 265, Center for Archaeological Research, The University of Texas at San Antonio; Archeology Studies Program, Report 3, Environmental Affairs Division, Texas Department of Transportation, Austin. 
Leffler, J. J.

2002 Ranchers, Farmers, Soldiers, and the CCC: The Background for Seven Historical Sites at Camp Bowie, Brown County, Texas. Archaeological Survey Report, No. 325. Center for Archaeological Research, The University of Texas at San Antonio.

Lukowski, P. D.

1988 Archaeological Investigations at 41BXI, Bexar County, Texas. Archaeological Survey Report, No. 135. Center for Archaeological Research, The University of Texas at San Antonio.

McClean, R. G., and W. F. Kean

1993 Contributions of Wood Ash Magnetism to Archeomagnetic Properties of Fire Pits and Hearths. Earth and Planetary Science Letters 119:387-394.

Mahoney, R. B.

2001a Camp Maxey III, Archaeological Testing of 23 Prehistoric Sites, Lamar County, Texas. Archaeological Survey Report, No. 314. Center for Archaeological Research, The University of Texas at San Antonio.

2001b Camp Maxey III, Archaeological Testing of 23 Prehistoric Sites, Lamar County, Texas: Map Supplement. Archaeological Survey Report, No. 314. Center for Archaeological Research, The University of Texas at San Antonio.

Mauldin, R. P., and C. J. Broehm

2001 An Archaeological Survey of 90 Acres at Camp Bowie, Brown County, Texas. Archaeological Survey Report, No. 319. Center for Archaeological Research, The University of Texas at San Antonio.

Meissner, B. A.

1993 Where the Buffalo Roam: Archaeological Evidence of Bison Populations in South and Central Texas. Manuscript on file, Center for Archaeological Research, The University of Texas at San Antonio.

Nance, H. S., and E. G. Wermund

1993 Geological and Climatic Survey: Camp Bowie Military Reservation, Brownwood, Texas. Bureau of Economic Geology, The University of Texas at Austin.

Nature Conservancy of Texas

1996 Land Cover Analysis of Texas Army National Guard Training Sites. Report submitted to the Texas Adjutant General's Department, Austin.

Nickels, D. L., C. B. Bousman, J. D. Leach, and D. A. Cargill

2001[1998] Test Excavations at the Culebra Creek Site, 41BX126, Bexar County, Texas. Archaeological Survey Report, No. 265, Center for Archaeological Research, The University of Texas at San Antonio; Archeology Studies Program, Report 3, Environmental Affairs Division, Texas Department of Transportation, Austin.

Patterson, L. W.

1988 Intergroup Conflict in Prehistoric Texas. Houston Archeological Society Journal 90:8-10.

Prewitt, E. R.

1974 Archeological Investigations at the Loeve-Fox Site, Williams County, Texas. Research Report 49. Texas Archeological Survey, The University of Texas at Austin.

1981 Culture Chronology in Central Texas. Bulletin of the Texas Archeological Society 52:65-89. 
1985 From Circleville to Toyah: Comments on Central Texas Chronology. Bulletin of the Texas Archeological Society 54:201-238.

1991 Burned Rock Middens: A Summary of Previous Investigations and Interpretations. InThe Burned Rock Middens of Texas: An Archeological Symposium, edited T. R. Hester, pp. 25-32. Studies in Archeology 13. Texas Archeological Research Laboratory, The University of Texas at Austin.

Prikryl, D. J.

1983 An Archaeological Survey of the City of Brownwood Proposed Sanitary Landfill Site, Brown County, Texas. Prewitt and Associates, Austin, Texas.

Reynolds, R. L., and J. W. King

1995 Magnetic Records of Climate Change. U.S. National Report to I.U.G.G., 1991-1994. American Geophysical Union. <http://www.agu.ong/revgeophys/reyno100/reyno100.html> Accessed May 2001.

Robinson, D. G., T. M. Meade, L. H. Kay, L. Gassaway, and D. Kay

2001 An Archaeological Inventory of Camp Swift, Bastrop County, Texas. Archaeological Survey Report, No. 316. Center for Archaeological Research, The University of Texas at San Antonio.

Shafer, H. J., E. P. Baxter, and P. Dering

1975a Upper Pecan Bayou Watershed, Brown County, Texas, An Archaeological Survey of Structure No. 30. Archaeological Research Laboratory, Texas A\&M University, College Station, Texas.

1975b Brownwood Laterals Watershed, Brown County Texas: Archaeological Surveys of Floodwater Retarding Structures 1, Z24, 5, 18, 24 and 2. Report No. 13, Archaeological Research Laboratory, Texas A\&M University, College Station, Texas.

Singer, M. J., and P. Fine

1989 Pedogenic Factors Affecting Magnetic Susceptibility of Northern California Soils. Soil Science of America Journal 53:1119-1127.

Skelton, D. W.

1977 Archeological Investigations at the Fayette Power Project, Fayette County, Texas. Research Report 60. Texas Archeological Survey, The University of Texas at Austin.

Skinner, S. A.

1981 Aboriginal Demographic Changes in Central Texas. Plains Anthropologist 26(92):111-118.

Steele, D. G., and C. Assad Hunter

1986 Analysis of Vertebrate Faunal Remains from 41MC222 and 41MC296, McMullen County, Texas. In The Prehistoric Sites at Choke Canyon Reservoir, Southern Texas: Results of Phase II Archaeological Investigations, edited by G. D. Hall, T. R. Hester, and S. L. Black. Choke Canyon Series, No. 10. Center for Archaeological Research, The University of Texas at San Antonio.

Story, D. A.

1985 Adaptive Strategies of Archaic Cultures of the West Gulf Coastal Plain. In Prehistoric Food Production in North America, edited by R. I. Ford, pp. 19-56. Anthropological Papers No. 75. Museum of Anthropology, University of Michigan, Ann Arbor.

Swanson, E. R.

1995 Geo-Texas. A Guide to the Earth Sciences. Texas A\&M University Press, College Station, Texas. 
Taylor, A. J., and C. L. Highley

1995 Archaeological Investigations at the Loma Sandia Site (41LK28): A Prehistoric Campsite in Live Oak County, Texas. 2 vols. Studies in Archeology No. 20. Texas Archeological Research Laboratory, The University of Texas at Austin.

Texas Parks and Wildlife Department

1994 Biological Inventory of Camp Bowie. Prepared for the Texas National Guard by the Texas Heritage Program Resource Protection Division of the Texas Parks and Wildlife Department, Austin, Texas.

Turner, E. S., and T. R. Hester

1993 A Field Guide to Stone Artifacts of Texas Indians. Gulf Publishing Company, Houston.

Weir, F. A.

1976 The Central Texas Archaic. Unpublished Ph.D. dissertation. Anthropology Department, Washington State University.

Wormser, A. J., and S. Sullo-Prewitt

2001 Cultural Resources Inventory of Camp Bowie, Brownwood, Texas. Archaeological Survey Report, No 317. Center for Archaeological Research, The University of Texas at San Antonio.

Wormser, A. J., G. P. Davis, and C. Leshley

1994 Archaeological Investigation of Proposed Camp Bowie Firebreak, Brown County, Texas. Adjutant General's Department of Texas. Manuscript on file, Texas Historical Commission, Austin, Texas.

Wormser, A. J., D. M. Sullo, and S. C. Stringer

1997 Archaeological Investigations of the Proposed Tank Training Area at Camp Bowie, Brown County, Texas. Adjutant General's Department of Texas. Manuscript on file, Texas Historical Commission, Austin, Texas. 


\section{Appendix A}

Shovel Test Data 
Table A-1. Shovel test data for Survey Parcel 1

\begin{tabular}{|c|c|c|c|c|}
\hline Parcel & Shovel Test \# & Max. Depth & Artifacts & Lev. of Artifacts \\
\hline 1 & T1ST1 & $60 \mathrm{~cm} \mathrm{bs}$ & 0 & \\
\hline 1 & T1ST2 & $60 \mathrm{~cm} \mathrm{bs}$ & 0 & \\
\hline 1 & $\mathrm{~T} 2 \mathrm{ST} 1$ & $60 \mathrm{~cm}$ bs & 0 & \\
\hline 1 & $\mathrm{~T} 2 \mathrm{ST} 2$ & $60 \mathrm{~cm}$ bs & 0 & \\
\hline 1 & T3ST1 & $60 \mathrm{~cm} \mathrm{bs}$ & 0 & \\
\hline 1 & T3ST2 & $60 \mathrm{~cm}$ bs & 0 & \\
\hline 1 & T3ST3 & $60 \mathrm{~cm}$ bs & 0 & \\
\hline 1 & T3ST4 & $60 \mathrm{~cm} \mathrm{bs}$ & 0 & \\
\hline 1 & T3ST5 & $60 \mathrm{~cm} \mathrm{bs}$ & 0 & \\
\hline 1 & T3ST6 & $60 \mathrm{~cm}$ bs & 0 & \\
\hline 1 & T3ST7 & $60 \mathrm{~cm}$ bs & 0 & \\
\hline 1 & T3ST8 & $50 \mathrm{~cm}$ bs & 0 & \\
\hline 1 & T3ST9 & $50 \mathrm{~cm}$ bs & 0 & \\
\hline 1 & T3ST10 & $50 \mathrm{~cm}$ bs & 0 & \\
\hline 1 & T3ST11 & $50 \mathrm{~cm} \mathrm{bs}$ & 0 & \\
\hline 1 & T3ST12 & $50 \mathrm{~cm}$ bs & 0 & \\
\hline 1 & T3ST13 & $40 \mathrm{~cm} \mathrm{bs}$ & 0 & \\
\hline 1 & T3ST14 & $50 \mathrm{~cm}$ bs & 0 & \\
\hline 1 & $\mathrm{~T} 4 \mathrm{ST} 1$ & $60 \mathrm{~cm} \mathrm{bs}$ & 0 & \\
\hline 1 & T4ST2 & $52 \mathrm{~cm} \mathrm{bs}$ & 0 & \\
\hline 1 & T4ST3 & $60 \mathrm{~cm} \mathrm{bs}$ & 0 & \\
\hline 1 & T4ST4 & $60 \mathrm{~cm} \mathrm{bs}$ & 0 & \\
\hline 1 & T4ST5 & $60 \mathrm{~cm} \mathrm{bs}$ & 0 & \\
\hline 1 & T4ST6 & $60 \mathrm{~cm} \mathrm{bs}$ & 0 & \\
\hline 1 & T4ST7 & $60 \mathrm{~cm} \mathrm{bs}$ & 0 & \\
\hline 1 & T4ST8 & $60 \mathrm{~cm} \mathrm{bs}$ & 0 & \\
\hline 1 & T4ST9 & $60 \mathrm{~cm} \mathrm{bs}$ & 1 debitage & $5(40-50 \mathrm{~cm} \mathrm{bs})$ \\
\hline 1 & T4ST10 & $60 \mathrm{~cm} \mathrm{bs}$ & 0 & \\
\hline 1 & T4ST11 & $60 \mathrm{~cm} \mathrm{bs}$ & 0 & \\
\hline 1 & T4ST12 & $60 \mathrm{~cm} \mathrm{bs}$ & 0 & \\
\hline 1 & T4ST13 & $60 \mathrm{~cm} \mathrm{bs}$ & 1 bone fragment & $3(20-30 \mathrm{~cm} \mathrm{bs})$ \\
\hline 1 & T4ST13 & $60 \mathrm{~cm} \mathrm{bs}$ & 1 bone fragmnet & $4(30-40 \mathrm{~cm} \mathrm{bs})$ \\
\hline 1 & T4ST14 & $60 \mathrm{~cm} \mathrm{bs}$ & 0 & \\
\hline 1 & T5ST1 & $60 \mathrm{~cm} \mathrm{bs}$ & 0 & \\
\hline 1 & T5ST2 & $60 \mathrm{~cm}$ bs & 0 & \\
\hline 1 & T5ST3 & $60 \mathrm{~cm} \mathrm{bs}$ & 0 & \\
\hline 1 & T5ST4 & $60 \mathrm{~cm}$ bs & 0 & \\
\hline 1 & T5ST5 & $60 \mathrm{~cm}$ bs & 0 & \\
\hline 1 & T5ST6 & $60 \mathrm{~cm}$ bs & 0 & \\
\hline 1 & T5ST7 & $60 \mathrm{~cm}$ bs & 0 & \\
\hline 1 & T5ST8 & $50 \mathrm{~cm}$ bs & 0 & \\
\hline 1 & T5ST9 & $60 \mathrm{~cm}$ bs & 0 & \\
\hline 1 & $\mathrm{~T} 6 \mathrm{ST} 1$ & $60 \mathrm{~cm}$ bs & 0 & \\
\hline 1 & $\mathrm{~T} 6 \mathrm{ST} 2$ & $60 \mathrm{~cm} \mathrm{bs}$ & 0 & \\
\hline 1 & T6ST3 & $40 \mathrm{~cm} \mathrm{bs}$ & 0 & \\
\hline 1 & T7ST1 & $70 \mathrm{~cm} \mathrm{bs}$ & 1 debitage & $5(40-50 \mathrm{~cm} \mathrm{bs})$ \\
\hline 1 & T8ST1 & $60 \mathrm{~cm} \mathrm{bs}$ & 0 & \\
\hline 1 & T8ST2 & $60 \mathrm{~cm}$ bs & 0 & \\
\hline
\end{tabular}


Table A-2. Shovel test data for Survey Parcel 2

\begin{tabular}{|c|c|c|c|c|}
\hline Parcel & Shovel Test \# & Max. Depth & Artifacts & Lev. of Artifacts \\
\hline 2 & T1ST1 & $20 \mathrm{~cm} \mathrm{bs}$ & 0 & \\
\hline 2 & T1ST2 & $18 \mathrm{~cm} \mathrm{bs}$ & 0 & \\
\hline 2 & T2ST1 & $12 \mathrm{~cm} \mathrm{bs}$ & 0 & \\
\hline 2 & $\mathrm{~T} 2 \mathrm{ST} 2$ & $27 \mathrm{~cm} \mathrm{bs}$ & 0 & \\
\hline 2 & T3ST1 & $25 \mathrm{~cm} \mathrm{bs}$ & 0 & \\
\hline 2 & T3ST2 & $40 \mathrm{~cm}$ bs & 0 & \\
\hline 2 & $\mathrm{~T} 4 \mathrm{ST} 1$ & $20 \mathrm{~cm} \mathrm{bs}$ & 0 & \\
\hline 2 & $\mathrm{~T} 4 \mathrm{ST} 2$ & $50 \mathrm{~cm} \mathrm{bs}$ & 0 & \\
\hline 2 & T5ST1 & $10 \mathrm{~cm} \mathrm{bs}$ & 0 & \\
\hline 2 & T5ST2 & $20 \mathrm{~cm} \mathrm{bs}$ & 0 & \\
\hline 2 & T6ST1 & $34 \mathrm{~cm} \mathrm{bs}$ & 0 & \\
\hline 2 & T6ST2 & $41 \mathrm{~cm} \mathrm{bs}$ & 0 & \\
\hline 2 & T7ST1 & $20 \mathrm{~cm} \mathrm{bs}$ & 0 & \\
\hline 2 & $\mathrm{~T} 7 \mathrm{ST} 2$ & $35 \mathrm{~cm}$ bs & 0 & \\
\hline 2 & T8ST1 & $12 \mathrm{~cm} \mathrm{bs}$ & 0 & \\
\hline 2 & T8ST2 & $60 \mathrm{~cm} \mathrm{bs}$ & 0 & \\
\hline 2 & T9ST1 & $60 \mathrm{~cm}$ bs & 0 & \\
\hline 2 & T9ST2 & $60 \mathrm{~cm} \mathrm{bs}$ & 0 & \\
\hline 2 & T10ST1 & $60 \mathrm{~cm} \mathrm{bs}$ & 0 & \\
\hline 2 & $\mathrm{~T} 10 \mathrm{ST} 2$ & $60 \mathrm{~cm} \mathrm{bs}$ & 0 & \\
\hline 2 & T11ST1 & $60 \mathrm{~cm}$ bs & 0 & \\
\hline 2 & $\mathrm{~T} 11 \mathrm{ST} 2$ & $10 \mathrm{~cm}$ bs & 0 & \\
\hline 2 & T11 ST3 & $31 \mathrm{~cm} \mathrm{bs}$ & 0 & \\
\hline 2 & $\mathrm{~T} 12 \mathrm{ST} 1$ & $60 \mathrm{~cm}$ bs & 0 & \\
\hline 2 & $\mathrm{~T} 12 \mathrm{ST} 2$ & $30 \mathrm{~cm}$ bs & 0 & \\
\hline 2 & $\mathrm{~T} 12 \mathrm{ST} 3$ & $40 \mathrm{~cm}$ bs & 0 & \\
\hline 2 & T13ST1 & $30 \mathrm{~cm} \mathrm{bs}$ & 0 & \\
\hline 2 & $\mathrm{~T} 13 \mathrm{ST} 2$ & $14 \mathrm{~cm} \mathrm{bs}$ & 0 & \\
\hline 2 & T14ST1 & $30 \mathrm{~cm} \mathrm{bs}$ & 0 & \\
\hline 2 & T14ST2 & $38 \mathrm{~cm} \mathrm{bs}$ & 0 & \\
\hline 2 & T15ST1 & $5 \mathrm{~cm} \mathrm{bs}$ & 0 & \\
\hline 2 & $\mathrm{~T} 15 \mathrm{ST} 2$ & $8 \mathrm{~cm} \mathrm{bs}$ & 0 & \\
\hline 2 & T16ST1 & $50 \mathrm{~cm}$ bs & 0 & \\
\hline 2 & $\mathrm{~T} 16 \mathrm{ST} 2$ & $40 \mathrm{~cm} \mathrm{bs}$ & 0 & \\
\hline
\end{tabular}


Table A-3. Shovel test data for Survey Parcel 3

\begin{tabular}{|c|c|c|c|c|}
\hline Parcel & Shovel Test \# & Max. Depth & Artifacts & Lev. of Artifacts \\
\hline 3 & T1ST1 & $56 \mathrm{~cm} \mathrm{bs}$ & 0 & \\
\hline 3 & T1ST2 & $60 \mathrm{~cm} \mathrm{bs}$ & 0 & \\
\hline 3 & T1ST3 & $60 \mathrm{~cm} \mathrm{bs}$ & 0 & \\
\hline 3 & T2ST1 & $40 \mathrm{~cm} \mathrm{bs}$ & 1 debitage & $1(0-10 \mathrm{~cm} \mathrm{bs})$ \\
\hline 3 & T2ST1 & $40 \mathrm{~cm} \mathrm{bs}$ & 1 debitage & $2(10-20 \mathrm{~cm} \mathrm{bs})$ \\
\hline 3 & $\mathrm{~T} 2 \mathrm{ST} 2$ & $60 \mathrm{~cm} \mathrm{bs}$ & 0 & \\
\hline 3 & T2ST3 & $28 \mathrm{~cm} \mathrm{bs}$ & 0 & \\
\hline 3 & T3ST1 & $50 \mathrm{~cm} \mathrm{bs}$ & 0 & \\
\hline 3 & T3ST2 & $39 \mathrm{~cm} \mathrm{bs}$ & 0 & \\
\hline 3 & T3ST3 & $27 \mathrm{~cm} \mathrm{bs}$ & 0 & \\
\hline 3 & T4ST1 & $39 \mathrm{~cm} \mathrm{bs}$ & 0 & \\
\hline 3 & T4ST2 & $45 \mathrm{~cm} \mathrm{bs}$ & 0 & \\
\hline 3 & T4ST3 & $60 \mathrm{~cm} \mathrm{bs}$ & 0 & \\
\hline 3 & T5ST1 & $60 \mathrm{~cm} \mathrm{bs}$ & 0 & \\
\hline 3 & T5ST2 & $44 \mathrm{~cm} \mathrm{bs}$ & 0 & \\
\hline 3 & T5ST3 & $60 \mathrm{~cm} \mathrm{bs}$ & 0 & \\
\hline 3 & T6ST1 & $30 \mathrm{~cm} \mathrm{bs}$ & 0 & \\
\hline 3 & T6ST2 & $30 \mathrm{~cm} \mathrm{bs}$ & 0 & \\
\hline 3 & T6ST3 & $45 \mathrm{~cm} \mathrm{bs}$ & 0 & \\
\hline 3 & T7ST1 & $40 \mathrm{~cm} \mathrm{bs}$ & 0 & \\
\hline 3 & T7ST2 & $30 \mathrm{~cm} \mathrm{bs}$ & 0 & \\
\hline 3 & T7ST3 & $50 \mathrm{~cm} \mathrm{bs}$ & 0 & \\
\hline 3 & T8ST1 & $60 \mathrm{~cm} \mathrm{bs}$ & 0 & \\
\hline 3 & T8ST2 & $50 \mathrm{~cm} \mathrm{bs}$ & 0 & \\
\hline 3 & T9ST1 & $28 \mathrm{~cm} \mathrm{bs}$ & 0 & \\
\hline 3 & T9ST2 & $38 \mathrm{~cm} \mathrm{bs}$ & 0 & \\
\hline 3 & T10ST1 & $20 \mathrm{~cm} \mathrm{bs}$ & 0 & \\
\hline 3 & T10ST2 & $60 \mathrm{~cm} \mathrm{bs}$ & 0 & \\
\hline 3 & T11ST1 & $35 \mathrm{~cm} \mathrm{bs}$ & 0 & \\
\hline 3 & T11ST2 & $57 \mathrm{~cm} \mathrm{bs}$ & 0 & \\
\hline 3 & $\mathrm{~T} 12 \mathrm{ST} 1$ & $44 \mathrm{~cm} \mathrm{bs}$ & 0 & \\
\hline 3 & T12ST2 & $23 \mathrm{~cm} \mathrm{bs}$ & 0 & \\
\hline 3 & T13ST1 & $56 \mathrm{~cm} \mathrm{bs}$ & 0 & \\
\hline 3 & T13ST2 & $20 \mathrm{~cm} \mathrm{bs}$ & 0 & \\
\hline 3 & T14ST1 & $38 \mathrm{~cm} \mathrm{bs}$ & 0 & \\
\hline 3 & T14ST2 & $50 \mathrm{~cm} \mathrm{bs}$ & 0 & \\
\hline 3 & T15ST1 & $60 \mathrm{~cm} \mathrm{bs}$ & 0 & \\
\hline 3 & T15ST2 & $40 \mathrm{~cm} \mathrm{bs}$ & 0 & \\
\hline 3 & $\mathrm{~T} 16 \mathrm{ST} 1$ & $50 \mathrm{~cm} \mathrm{bs}$ & 0 & \\
\hline 3 & T16ST2 & $31 \mathrm{~cm} \mathrm{bs}$ & 0 & \\
\hline 3 & T17ST1 & $45 \mathrm{~cm} \mathrm{bs}$ & 0 & \\
\hline 3 & T18ST1 & $21 \mathrm{~cm} \mathrm{bs}$ & 0 & \\
\hline 3 & T19ST1 & $40 \mathrm{~cm} \mathrm{bs}$ & 0 & \\
\hline 3 & T19ST2 & $20 \mathrm{~cm} \mathrm{bs}$ & 0 & \\
\hline
\end{tabular}


Table A-4. Shovel test data for tested sites

\begin{tabular}{|c|c|c|c|c|}
\hline Site & Shovel Test \# & Max. Depth & Artifacts & Lev. of Artifacts \\
\hline 41BR248 & ST1 & $60 \mathrm{~cm} \mathrm{bs}$ & 0 & \\
\hline 41BR248 & ST2 & $60 \mathrm{~cm} \mathrm{bs}$ & 0 & \\
\hline 41BR248 & ST3 & $60 \mathrm{~cm} \mathrm{bs}$ & 0 & \\
\hline 41BR248 & ST4 & $60 \mathrm{~cm} \mathrm{bs}$ & 0 & \\
\hline 41BR392 & ST1 & $25 \mathrm{~cm} \mathrm{bs}$ & 0 & \\
\hline 41BR392 & ST2 & $50 \mathrm{~cm} \mathrm{bs}$ & 1 shotgun shell cap & $2(10-20 \mathrm{~cm} \mathrm{bs})$ \\
\hline 41BR392 & ST2 & $50 \mathrm{~cm} \mathrm{bs}$ & 1 flake, 1 shell fragment & $5(40-50 \mathrm{~cm} \mathrm{bs})$ \\
\hline 41BR392 & surface coll. & 0 & 1 projectile point & 0 \\
\hline
\end{tabular}

\begin{tabular}{|l|l|l|l|l|}
\hline 41BR467 & ST1 & $8 \mathrm{~cm} \mathrm{bs}$ & 0 & \\
\hline 41BR467 & ST2 & $15 \mathrm{~cm} \mathrm{bs}$ & 0 & \\
\hline 41BR467 & ST3 & $13 \mathrm{~cm} \mathrm{bs}$ & 0 & \\
\hline 41BR467 & ST4 & $19 \mathrm{~cm} \mathrm{bs}$ & 0 & \\
\hline
\end{tabular}

\begin{tabular}{|l|l|l|c|c|}
\hline 41BR469 & ST1 & $42 \mathrm{~cm} \mathrm{bs}$ & 0 & \\
\hline 41BR469 & ST2 & $11 \mathrm{~cm} \mathrm{bs}$ & 0 & \\
\hline 41BR469 & ST3 & $26 \mathrm{~cm} \mathrm{bs}$ & 0 & \\
\hline 41BR469 & ST4 & $24 \mathrm{~cm} \mathrm{bs}$ & 0 & $1(0-10 \mathrm{~cm} \mathrm{bs})$ \\
\hline 41BR469 & ST5 & $30 \mathrm{~cm} \mathrm{bs}$ & 1 debitage & \\
\hline 41BR469 & ST6 & $14 \mathrm{~cm} \mathrm{bs}$ & 0 & \\
\hline
\end{tabular}

\begin{tabular}{|l|l|l|c|c|}
\hline 41BR471 & ST1 & $46 \mathrm{~cm} \mathrm{bs}$ & 1 debitage & $1(0-10 \mathrm{~cm} \mathrm{bs})$ \\
\hline 41BR471 & ST2 & $60 \mathrm{~cm} \mathrm{bs}$ & 0 & \\
\hline 41BR471 & ST3 & $51 \mathrm{~cm} \mathrm{bs}$ & 0 & \\
\hline 41BR471 & ST4 & $38 \mathrm{~cm} \mathrm{bs}$ & 0 & \\
\hline
\end{tabular}

\begin{tabular}{|l|c|c|c|c|}
\hline 41BR522 & E2 & $60 \mathrm{~cm}$ bs & 3 debitage & $1(0-10 \mathrm{~cm} \mathrm{bs})$ \\
\hline 41BR522 & $\mathrm{E} 2$ & $60 \mathrm{~cm}$ bs & 2 debitage & $2(10-20 \mathrm{~cm} \mathrm{bs})$ \\
\hline 41BR522 & $\mathrm{E} 3$ & $60 \mathrm{~cm}$ bs & 1 debitage, 1 projectile point & $3(20-30 \mathrm{~cm} \mathrm{bs})$ \\
\hline 41BR522 & $\mathrm{N} 1$ & $50 \mathrm{~cm} \mathrm{bs}$ & 3 debitage & $1(0-10 \mathrm{~cm} \mathrm{bs})$ \\
\hline 41BR522 & $\mathrm{N} 2$ & $60 \mathrm{~cm} \mathrm{bs}$ & 0 & \\
\hline 41BR522 & $\mathrm{S} 1$ & $60 \mathrm{~cm}$ bs & 0 & \\
\hline 41BR522 & $\mathrm{S} 2$ & $60 \mathrm{~cm}$ bs & 0 & \\
\hline
\end{tabular}

